\title{
STEM Eğitimi İçin Bir Temellendirme: Ortaokul Öğrencilerinin Bilim İnsanı ve Mühendis Algıları1
}

\section{Ebru Öztürk İrtem²}

\author{
Hanife Gamze Hastürk ${ }^{3}$
}

Type/Tür:

Research/Araştırma

Received/Geliş Tarihi: April

10/ 10 Nisan 2021

Accepted/Kabul Tarihi:

August 5/ 5 Ağustos 2021

Page numbers/Sayfa No:

1327-1355

Corresponding

Author/İletişimden Sorumlu

Yazar:

gamzeyalvac@gmail.com

\section{$\checkmark$ iThenticate}

This paper was checked for plagiarism using iThenticate during the preview process and before publication. / $\mathrm{Bu}$ çalışma ön inceleme sürecinde ve yayımlanmadan önce iThenticate yazılımı ile taranmiştır.

\section{Copyright $(2017$ by} Cumhuriyet University, Faculty of Education. All rights reserved.

\section{Öz}

Araştıran, sorgulayan, üreten ve yenilikçi bireylerin yetişmesinin amaçlandığı günümüz eğitim programlarında STEM eğitimi ön plana çıkmaktadır. STEM (Science, Technology, Engieering ve Mathematics); fen, teknoloji, mühendislik ve matematik kelimelerinin baş harflerinden oluşan, bilim ve mühendislik alanlarında kariyer seçimi, girişimcilik, yenilikçilik, yaratıcı ve eleştirel düşünme gibi 21. yüzyıl becerilerini geliştiren bir yaklaşımdır. STEM eğitiminin tam olarak amacına ulaşabilmesi için öğrencilerin bilim ve mühendis algılarının tespit edilmesi, gerçekleştirilecek uygulamaların temellendirilmesi açısından oldukça önemlidir. $\mathrm{Bu}$ nedenle araştırmada ortaokul öğrencilerinin bilim insanı ve mühendis algılarının belirlenmesi amaçlanmıştır. Araştırma, 2019-2020 eğitim-öğretim y1lı güz döneminde tamamlanmıştır. Araştırma modeli olarak tarama modeli kullanılmıştır. Bu bağlamda Türkiye' de Orta Karadeniz bölgesinde yer alan bir il merkezinde bulunan 12 devlet okulunda öğrenim gören öğrenciler ile araştırma gerçekleştirilmiştir. Araştırmada veri toplama aracı olarak Chambers (1983) tarafından geliştirilen "Bir Bilim İnsanı Çiz Testi" ve Knight ve Cunningham (2004) tarafından geliştirilen "Bir Mühendis Çiz Testi" kullanılmıştır. Çalışmada "Bir Bilim İnsanı Çiz" testine 545, "Bir Mühendis Çiz" testine 521 öğrenci katılmıştır. Elde edilen veriler içerik analizine tabii tutulmuştur. Çalışmanın sonucunda bilim insanı ve mühendis cinsiyeti olarak öğrencilerin daha çok erkek bilim insanı ve erkek mühendis çizdiği görülmüştür. Bilim insanı çalışma ortamı olarak laboratuvar ve laboratuvar araç gereçleri ile resmettikleri de görülmüştür. Günümüz öğretim programlarında, STEM eğitiminde bilim insanı ve mühendisliğe ilişkin kazanımlar yer almasına rağmen öğrencilerin geleneksel düşüncelere sahip olması dikkat çekici bir sonuç olarak karşımıza çıkmaktadır. Bu nedenle elde edilen bulgular ışığında STEM eğitiminin önemine dikkat çekilmiş ve bu konuda program belirleyicilere, araştırmacılara ve uygulayıcılara yönelik önerilerde bulunulmuştur.

Anahtar Kelimeler: STEM, bilim insanı, DAST, bilim insanı algısı, mühendis algisı

\section{Suggested APA Citation/Önerilen APA Atıf Biçimi:}

Öztürk İrtem, E., \& Hastürk, H., G. (2021). STEM eğitimi için bir temellendirme: ortaokul öğrencilerinin bilim insanı ve mühendis algıları. Cumhuriyet International Journal of Education, 10(3), 1327-1355. http://dx.doi.org/10.30703/cije.912794

\footnotetext{
${ }^{1}$ Bu çalışma, birinci yazarın ikinci yazar danışmanlığında hazırlanan yüksek lisans tezinin bir bölümünden üretilmiştir.

2 Öğretmen, Emirseyit Ortaokulu, Tokat/Türkiye

Teacher, Emirseyit Middle School, Tokat/Turkey

e-mail: pedagog_ebru@hotmail.com ORCID ID: orcid.org/0000-0003-2992-9887
}

${ }^{3}$ Dr. Öğr. Üyesi, Tokat Gaziosmanpaşa Üniversitesi, Tokat/Türkiye

Asst. Prof. Dr., Tokat Gaziosmanpaşa University, Tokat/Turkey.

e-mail: gamzeyalvac@gmail.com ORCID ID: orcid.org/0000-0002-8495-560X 


\title{
A Foundation for STEM Education: Secondary School Students' Images of Engineer and Scientist
}

\begin{abstract}
STEM education is at the forefront in today's education programs, where it is aimed to raise the individuals who are researching, questioning, producing and innovative. STEM consisting of the initial letters of the words 'science, technology, engineering and mathematics' is an approach that develops 21st century skills such as career choice, entrepreneurship, innovation, creative and critical thinking in science and engineering. In order that STEM education can fully achieve its purpose, it is very important to determine students' science and engineer perceptions in terms of grounding the applications to be carried out. Therefore, in the study, it was aimed to determine the middle school students' perceptions about scientist and engineer. The study was completed in the fall semester of the 2019-2020 academic year. Survey model was used in the study. In this context, the study was carried out with 12 students studying in state schools in the center of a province located in the Central Black Sea in Turkey. The "Draw a Scientist Test" developed by Chambers (1983) and the "Draw an Engineer Test" developed by Knight and Cunningham (2004) were used as data collection tools in the study. In the study, 545 students participated in the "draw a scientist" test while 21 students took the "draw an engineer" test. Content analysis was conducted for the obtained data. In the content analysis, the answers and drawings of the students were evaluated by creating codes and themes. As a result of the study, it was seen that the students mostly drew male scientists and male engineers as scientists and engineers. It has also been seen that they portray them with laboratory and laboratory equipment as a scientist working environment. Although there are acquisitions regarding scientists and engineering in STEM education in today's curricula, it is a striking result that students have traditional thoughts. Therefore, in the light of the findings, the importance of STEM education was emphasized, so the recommendations were made to program designers, researchers and practitioners.
\end{abstract}

Keywords: STEM, scientist, DAST, image of scientist, image of engineer

\section{Giriş}

Bilim ve teknolojideki değişiklikler, birçok alanda olduğu gibi, endüstriyel bir toplumdan bilgi toplumuna geçildiği için eğitim sistemini de değiştirmiştir (Akpınar ve Aydın, 2007). Bu değişikliklerin sonucunda toplumun yeni ihtiyaçları ortaya çıkmıştır. Toplumun geleceğini bilim ve teknolojinin hızına ayak uyduran bireyler belirlemektedir. Toplumların yaşadığımız çağa uyum sağlayabilmeleri için problemlere çözümler üretebilen ve yeni ürünler ortaya koyabilen bireylere ihtiyac1 vardir (National Academy of Engineering and National Research Council, 2014; National Research Council [NRC], 2012). 21. yüzyılda bilim ve teknolojideki gelişmeler bir yarış haline gelmiş ve hız kazanmıştır. Bu da ülkelerin mühendislik eğitimine ve inovasyon sürecine önem vermesine sebep olmuştur.

Fen eğitimi temelinin araştırmaya dayandırılması, paydaşların (öğretmenler, öğrenciler, uzmanlar, ebeveynler, vb.) motivasyon ve iş birliğini arttırmak için daha fazla ağın kurulmasını gerektirmiştir. Söz konusu ihtiyaçların karşılanması için yeni bir sistem olan STEM (Science, Technology, Engieering ve Mathematics) eğitimi geliştirilmiş ve hayata geçirilmiştir (Dugger, 2010; Lantz, 2009). Doksanlı yılların sonlarında öncelikle ABD'de dikkat çekilmeye başlayan STEM, kısa sürede Avrupa ve Asya ülkelerinin ilgisini çekerek bu ülkelerin eğitim sistemlerinde yerini almıştır (Blackley ve Howell, 2015). Avrupa Birliği (AB), 2007 yılında "Şimdi Bilim Eğitimi: 
Avrupa'nın Geleceği İçin Yenilenmiş Pedagoji" başlıklı bir inceleme raporu yayınlamıştır (Robert, 2012). Bu rapor Avrupa'nın fen ve teknoloji eğitiminde yaşadığı sorunlara değinmiş ve özellikle gençlerin bilim hakkındaki bilgilerinin önemli ölçüde azaldığına dikkat çekmiştir. STEM; fen, teknoloji, mühendislik ve matematik kelimelerinin baş harflerinden oluşmaktadır. Sanders'a (2009) göre STEM eğitimi, bu dört alanın aynı anda olmasa bile en az iki disiplinin bir araya gelerek oluşturduğu eğitim yaklaşımı olarak görülmektedir. STEM eğitimi, öğrencilerin karşılaştıkları sorunlara multidisipliner bir yaklaşımla yaklaşmayı ve bütüncül bir eğitim yapısı ile bilgi ve beceri kazanmayı amaçlamaktadır (Şahin, Ayar ve Adıgüzel, 2014). STEM eğitimi, okulun başlangıcından başlayarak yükseköğretime kadar devam eden ve tüm eğitim sürecini kapsayan çok disiplinli bir yaklaşım olarak görülmektedir (Çorlu ve Aydın, 2016; León, Núñez ve Liew, 2015; NRC, 2011; OECD, 2018).

STEM eğitimi, farklı ama bağlantılı disiplinleri bir araya getirerek daha kaliteli öğrenme sağlar. Sonuçta ortaya çıkan öğrenme çıktıları yani ürünler günlük yaşamda kullanımını, yaşam standartlarını yükseltmeyi ve eleştirel düşünmeyi içeren bir eğitim sürecine dahil olarak düşünülebilir (Yıldırım ve Altun, 2015). STEM eğitimi, öğrencileri ve eğitmenleri doğrudan öğrenmeye teşvik eder (Çakıroğlu, 2016). Örneğin öğrenciler ürettikleri projeleri kendi zihinlerinde tasarlayabilir ve uygulayabilirler (Özdemir, 2016). STEM eğitimi üzerine çalışmalar; bilim, teknoloji, mühendislik ve matematikteki teorik bilgilerin belirli bir süre sonra uygulanıp ürüne dönüştürülmesi açısından çok önemlidir (Çorlu, 2014; Yılmaz, Gülgün ve Çağlar, 2017). Bir eğitimin STEM eğitim yaklaşımında sayılabilmesi için; problem durumunun günlük yaşam ile ilgili olması, bulunan çözüm yolunun uygulanabilir olması ve bütünleşik öğretim sağlanabilmesi gibi özellikleri taşıması gerekmektedir (Chen, 2007; Lou, Shih, Diez ve Tseng, 2011; Tsai, 2007). Etkili bir STEM eğitimi ile öğrencilerin bilim ve mühendislik alanlarında kariyer seçmelerinin ve girişimcilik, yenilikçilik, yaratıcı ve eleştirel düşünme gibi 21. yüzyıl becerilerini edinmelerinin önü açılacağı düşünülmektedir. Ayrıca teknolojik açıdan nitelikli çalışanların yetiştirilmesi, hızlı gelişen teknoloji ve inovasyonlara ayak uydurabilecek toplumlar için gereklidir. STEM eğitimi sürecinde amaç sadece bilgi ve beceri kazandırmak değil aynı zamanda mesleğe yönelik de farkındalık oluşturmaktır. Bu bağlamda öğrencilerin bilim insanı ve mühendislik mesleği ile ilgili bir kariyere sahip olma eğilimlerin de de algıları ve zihinlerindeki algıları önemlidir (Knight ve Cunningham, 2004). İlk olarak 1957 yılında Mead ve Metraux tarafından bilim insanı algısı üzerinde yapılan çalışma Chambers tarafından 1983 yılındaki bilim insanı alsını çizmle ölçen test üzerine daha gelişmiştir (Buldu, 2006; Finson, 2002; Kaya, Doğan ve Öcal, 2008)). Daha önce farklı öğretim kademelerindeki öğrencilerde bilim insanı algısının belirlenmesi, üstün zekalı öğrencilerde bilim ve bilim insanı algısının belirlenmesi ve sınıf öğretmeni adaylarının STEM eğitimi yaklaşımı ile mühendislik ve teknoloji algılarına etkisinin incelenmesi gibi benzer çalışmalar yapılmıştır (Capobianco, Diefes-Dux, Mena ve Weller, 2011; Fralick, Kearn, Thompson ve Lyons, 2009; Yar, 2017). Ancak ilgili alan yazın incelendiğinde hem bilim insanı hem de mühendis algılarının birlikte ele alındığı ortaokul öğrencilerine yönelik çalışmalara az sayıda rastlanılmıştır. Rastlanan çalışmalarda da öğrencilerin bilim insanı hakkında genel kalıp yargilara sahip olduğu mühendislik hakkında bilgiye sahip olmadıklarına ulaşılmıştır (Barman, Ostlund, Gatto ve Halferty, 1997; Chambers, 1983; Finson, 2002; 
Fralick, Kearn, Thompson ve Lyons, 2009; Gülhan ve Şahin, 2018; Gonsoulin, 2001; Kara ve Akarsu, 2013; Kaya ve diğerleri, 2008; Küçük ve Bağ, 2012; Newton ve Newton, 1998; Özel, 2012; Song ve Kim, 1999). Ayar ve Saka (2014) araştırmalarında, öğrencilerinin mühendislik alanlarına olan ilgilerinin gelişmesini sağlayan etmenleri belirlemeyi amaçlamışlar ve hazırlanan STEM etkinliklerin yer aldığı bir eğitimde öğrencilerin mühendislik alanlarına olan ilgilerin artmasına neden olduğunu belirlemişlerdir. Ayrıca bu yanılgıyı ortadan kaldırmak için öneri olarak STEM eğitimi önerilmektedir. Bu da bize bir kez daha STEM eğitiminin bilim insanı ve mühendis algısı üzerindeki etksini göstermektedir. Bu çalışma ile öğrencilerin, mühendislik ile bilim insanı algılarının incelenmesinin STEM eğitimi alanında yapılacak çalışmalara katkı sunacağı düşünülmektedir. Bu bağlamda bu çalışmanın alan yazına katkı sağlayacağı düşünülmektedir.

İfade edilen özelliklerden hareketle, bu araştırmanın amacı ortaokul öğrencilerin bilim insanı ve mühendis algılarının belirlenmesidir. Bu doğrultuda, öğrencilerin zihninde bulunan bilim insanı ve mühendis tanımları, bilim insanı ve mühendisin çalışma ortamlarını, çalışma alanlarını, malzemelerini, yaptıkları işle ilgili görüşlerini belirlemek amaçlanmıştır.

$\mathrm{Bu}$ amaç ile araştırmanın problem cümlesi "Ortaokul öğrencilerinin bilim insanı ve mühendis algıları nasıldır?" şeklindedir. Bu araştırma sorusuna cevap aramak amacı ile aşağıda sunulan alt problemlere cevap aranmıştır.

Ortaokul beşinci, altıncı ve yedinci sınıf öğrencilerinin;

1. 'Bilim İnsanı Çiz' testine göre bilim insanının cinsiyeti, çalışma alanı/ortamı, çalışma malzemeleri değişkenleri bakımından cinsiyet ve sınıf düzeyi dağılımları nasıldır?

2. 'Mühendis Çiz' testine göre mühendisin cinsiyeti, çalışma alanı/ortamı, çalışma malzemeleri değişkenleri bakımından cinsiyet ve sınıf düzeyi dağılımları nasıldır?

\section{Araştırma Modeli}

\section{Yöntem}

Ortaokul öğrencilerinin bilim insanı ve mühendis algılarının inceleme konusu yapıldığı bu çalışmada nitel metodoloji esas alınmıştır (Merriam \& Tisdell, 2015). Bu bağlamda nitel araştırma desenlerinden durum çalışmasından faydalanılmıştır. Durum çalışması; araştırmacının zaman ile sınırlandırılmış bir veya birkaç durumu çoklu kaynakları içeren veri toplama araçları ile derinlemesine incelendiği nitel bir araştırma yaklaşımıdır (Yıldırım ve Şimşek, 2008; Yin, 2003)

\section{Çalışma Grubu}

Araştırmanın evrenini, 2019-2020 eğitim-öğretim yılında güz döneminde Türkiye' de Orta Karadeniz Bölgesinde yer alan bir ilin, ortaokullarda beşinci, altıncı ve yedinci sınıflarda öğrenim gören tüm öğrenciler oluşturmaktadır. Araştırmanın çalışma grubunu belirleyebilmek için uygun örnekleme yöntemi kullanılmıştır (Yıldırım ve Şimşek, 2008). Uygun örnekleme yönteminde "yakın çevrede bulunan ve ulaşılması kolay, elde mevcut ve araştırmaya katılmak isteyen (gönüllü) bireyler üzerinde" çalışma yapılabilir (Erkuş, 2009, s. 98). Ayrıca zaman, para ve iş gücü açısından da uygulama yapılabilir okulların seçilmesi örneklemin kolay ulaşılabilirliğini 
sağlamaktadır (Büyüköztürk, Kılıç, Akgün, Karadeniz, Demirel, 2013, s. 92). Araştırmaya göre bu çalışmada örnekleme birimi yakın çevrede, kolay ulaşılabilen ortaokullardır. Gözlem birimi ise bu okullarda öğrenim gören tüm beşinci, altıncı ve yedinci sınıf öğrencileridir. Çalışmada “Bir Bilim İnsanı Çiz" testine 545, “Bir Mühendis Çiz" testine 521 öğrenci katılmıştır.

Bilim insanı çiz ve mühendis çiz testi çalışma grubunun toplam öğrenci sayısı ve cinsiyetlere göre ayrımı tablolarda sunulmuştur. Tablo 1'de Bilim İnsanı Çiz testi uygulanan öğrencilere ait sınıf ve cinsiyet dağılımı frekans ve yüzde olarak verilmiştir.

Tablo 1

Bilim İnsanı Çiz Testine Katılan Öğrencilerin Cinsiyet ve Sınıf Dağılımına Yönelik Bilgiler

\begin{tabular}{llll}
\hline & & F & \% \\
\hline Kiz & Cinsiyet & & \\
Erkek & & 260 & 47.70 \\
& & 285 & 52.29 \\
5. Sinif & & 111 & \\
6. Sinif & & 158 & 20.36 \\
7. sinif & & 276 & 28.99 \\
& & 545 & 50.64 \\
\hline
\end{tabular}

Bilim İnsanı Çiz testine katılım sağlayan toplam öğrenci sayısı 545'tir. Araştırmaya katılan öğrencilerden \%47.70'i k1z (260) ve \%52.29'i erkek (285) öğrencidir. Bu öğrencilerin \%20.36 (111) beşinci sınıf, \%28.99 (158) altıncı sınıf, \%50.64 (276) yedinci sınıf öğrencisidir.

Tablo 2'de ise Mühendis Çiz testine katılan öğrencilere ait sinıf ve cinsiyet dağılımı frekans ve yüzde olarak sunulmuştur.

Tablo 2

Mühendis Çiz Testine Katılan Öğrencilerin Cinsiyet ve Sınıf Dă̆ılımına Yönelik Bilgiler

\begin{tabular}{llll}
\hline & & F & $\%$ \\
\hline Kiz & Cinsiyet & & \\
Erkek & & 246 & 47.21 \\
& & 275 & 52.78 \\
5. sinif & Sinif & 144 & 27.63 \\
6. sinif & & 173 & 33.20 \\
7. sinif & & 204 & 39.15 \\
& Toplam & 521 & 100 \\
\hline
\end{tabular}

Mühendis Çiz testine katılım sağlayan öğrenci sayısı 521 kişidir. Bu ortaokul öğrencilerinden \%47.21 k1z (246) ve \%52.78 erkek (275)'tir. Katılım sağlayan öğrencilerin \%27.63 (144) beşinci sınıf, \%33.20 (173) altıncı sınıf, \%39.15 (204) yedinci sinıf öğrencileri şeklindedir. 


\section{Veri Toplama Araçları}

Bir Bilim İnsanı Çiz Testi. Bir Bilim İnsanı Çiz testi tek sorudan oluşan bir ölçme aracıdır. İlk kez Chambers (1983) tarafından kullanılmıştır. Chambers (1983) bu ölçeğin anaokulundan beşinci sınıflara kadar olan öğrenciler ile uygulamasını yapmıştır. Ölçeğin analizinde bazı göstergeler için çizimde bulunup bulunmamasına göre ölçek değerlendirilmektedir. Buna göre Chambers (1983); cinsiyet, laboratuvar önlüğü, deney gözlüğü, araştırma araçları, laboratuvar malzemeleri, bilgi sembolleri; kitaplar, dolaplar gibi ifadeler yönünden verilerin analizinin yapilabileceğini belirtmiştir. Schibeci ve Sorensen (1983) bu ölçeğin güvenirlik çalışmasını yapmışlar ve 0.78 ile 0.98 arasında değişen kodlayıcılar arası benzerliğe ulaşmışlardır. Bu nedenle ölçeğin ortaokul öğrencilerinin bilim insanı ile ilgili algılarını ortaya çıkarmak için geçerli ve güvenilir bir ölçek olduğu söylenebilir.

Bir Mühendis Çiz Testi. Bu test, "Bir Bilim İnsanı Çiz" testinde olduğu gibi tek sorudan oluşan "Bir Mühendis Çiz Testi" olarak Knight ve Cunningham (2004) tarafından geliştirilmiştir. İlkokul üçüncü sınıftan lise on ikinci sınıfa kadar öğrenim gören toplam 384 öğrenci ile ölçeğin uygulaması yapılmıştır (Knight ve Cunningham, 2004). Ölçeği altıncı sınıflar ile uygulayan Karataş (2017), ölçeğin analizi için görünüm, objeler, mühendisin ne yaptığı ve çalışma ortamı kriterleri açısından ölçeğin analizini gerçekleştirmiştir. Benzer şekilde bu çalışmada da araştırmada veri analizi olarak doküman incelemesi yapılmıştır ve öğrencilerin bir mühendis ya da mühendisler çizmeleri ve bu mühendis ya da mühendislerin ne yaptığının yazılı olarak açıklanması istenmiştir. $\mathrm{Bu}$ sayede veri çeşitliliğini sağlamak ve güvenirliği artırmak amaçlanmıştır (Johnson, 2014; Patton, 2002).

\section{Veri Toplama Süreci}

Araştırma Türkiye'de Orta Karadeniz Bölgesinde yer alan bir il merkezinde bulunan devlet okullarında gerçekleştirilmiştir. Araştırmada uygulanan testler beşinci, altıncı ve yedinci sınıfta öğrenim gören ortaokul öğrencilerine (Bilim İnsanı Çiz Testi (f:545), Mühendis Çiz Testi (f:521) sınıf ortamında araştırmacı tarafından uygulanmıştır. Uygulama iki ayda tamamlanmıştır. Katılımcıların gerçek görüş ve düşüncelerini rahatlıkla ifade edebilmeleri için ölçeklere isim yazılmaması gerektiği vurgulanmıştır. Öğrencilere çizimlerinin ya da cevaplarının doğru ya da yanlış olarak değerlendirilmeyeceği ifade edilmiştir. Katılımcılara gerçek düşüncelerini ifade etmelerinin araştırma sonuçlarının geçerliği açısından önemli olduğu belirtilmiştir. Öğrencilere ‘Bilim İnsanı Çiz' ve 'Mühendis Çiz' formu verilerek işi başında çalışan bir bilim insanı ve mühendisi ziyaret ettiklerini düşünmelerini ve bu kişilerin nasıl çalıştığını, neler yaptığını, çalışma ortamlarını detaylandırarak verilen kağıtlara çizmeleri istenmiştir. Çizim yaparken renkli kalemler kullanmaları serbest birakılmıştır.

\section{Verilerin Analizi}

'Bilim İnsanı Çiz' ve 'Mühendis Çiz' testlerinde toplanan dokümanların analiz sürecinde alan uzmanlarından ve fen bilimleri öğretmeninden görüş alınarak içerik analizine tabii tutulmuştur. Yapılan içerik analizinde öğrencilerin verdikleri cevaplar ve çizimler kodlar ve temalar oluşturularak değerlendirilmiştir. İçerik analizi, elde edilen nitel veriler içerisinde tekrar eden kavramların belirlenmesi ve yorumlanması 
olarak ifade edilmektedir (Miles, Huberman, 1994; Silverman, 2000). Daha sonra tekrar eden kodlar kategorize edilip temalaştırılmıştır (Stake, 1995). Elde edilen temalara göre ayrıştırılan veriler frekans ve yüzde değerlerinde tablolar şeklinde sunulmuştur. Araştırmanın güvenirliğini sağlamak amacıyla araştırmacıların oluşturduğu kodlar ve eşleştirildiği temalar bir araya gelerek karşılaştırılmıştır. Karşılaştırmalarda görüş birliği ve görüş ayrılığ1 sayıları tespit edilerek veri analizinin güvenirliği, güvenirlik=görüş birliği/görüş birliği + görüş ayrılığı formülü (Miles ve Huberman, 1994) kullanılarak hesaplanmıştır. Yapılan hesaplama sonucunda, araştırmanın güvenirliği 0.92 olarak hesaplanmıştır. Bilim İnsanı Çiz testinde verilen cevaplar temalaştırıldığında, bilim insanı özellikleri (cinsiyeti), bilim insanının çalışma ortamı özellikleri (ortam türü, araç-gereç ve eşya) bakımından incelenmiştir. Mühendis Çiz testine verilen cevaplar incelendiğinde mühendisin özellikleri (cinsiyeti, dış görünüşü, çalışma alanı, branşı) ve çalışma ortamı (ortam türü, araçgereç ve eşyaları) şeklinde temalaştırılmıştır.

\section{Bulgular}

Öğrencilerin 'Bilim İnsanı Çiz' Testinden Elde Edilen Bulgular

Araştırmanın bu bölümünde öğrencilerin Bilim İnsanı Çiz testine vermiş oldukları cevapları; cinsiyet ve sınıf düzeyi değişkenlerinin bilim insanın cinsiyeti, çalışma ortamı ve çalışma malzemeleri açısından görüşlerinin değerlendirilmesi amaçlanmıştır. Bu amaçla Bilim İnsanı Çiz testinden elde edilen tüm veriler düzenlenmiş ve analiz edilmiştir.

\section{Bilim İnsanının Cinsiyeti}

Bilim insanı çizimlerinde elde edilen bilim insanının cinsiyetine yönelik bulguların cinsiyet ve sınıflara göre frekans ve yüzde dağılımları Tablo 3’de verilmiştir.

Tablo 3

Bilim İnsan Çizimlerinde Elde Edilen Bilim İnsanının Cinsiyetine Yönelik Bulguların Cinsiyet ve Sinıflara Göre Frekans ve Yüzde Dağılımları

\begin{tabular}{llllllll}
\hline Bilim insanı & & Kız & Erkek & 5.sınıf & 6. sınıf & 7. sınıf & Toplam \\
\hline Kadın & $\mathrm{f}$ & 40 & 8 & 14 & 14 & 20 & 48 \\
& $\%$ & 7.33 & 1.46 & 2.56 & 2.56 & 3.66 & 8.80 \\
Erkek & $\mathrm{f}$ & 137 & 269 & 80 & 107 & 219 & 406 \\
& $\%$ & 25.13 & 49.35 & 14.67 & 19.63 & 40.18 & 74.49 \\
Kadın ve erkek & $\mathrm{f}$ & 21 & 40 & 17 & 21 & 23 & 61 \\
bir arada & $\%$ & 3.85 & 7.33 & 3.11 & 3.85 & 4.22 & 11.19 \\
İnsan figürü yok & $\mathrm{f}$ & 10 & 20 & 15 & 8 & 7 & 30 \\
& $\%$ & 1.83 & 3.66 & 2.75 & 1.46 & 1.28 & 5.50 \\
\hline
\end{tabular}

Tablo 3 incelendiğinde, çalışmaya katılan öğrencilerden \%8.80'i (48) çizimlerinde bilim insanını kadın olarak çizerken \%74.49'u (406) bilim insanını erkek olarak çizmiştir. Öğrencilerin \%5.50'i (30) insan figürü kullanmazken \%11.19’u (61) kadın ve erkek bilim insanını beraber çalışırken göstermiştir. Çalışmadan elde edilen bir diğer sonuç da kadın bilim insanı içeren çizimlerin sadece \% 7'si erkek öğrenciler tarafından, \%1'i ise kız öğrenciler tarafından yapılmıştır. Kadın ve erkek bilim insanını bir arada çizimlerin oranı ise kız öğrencilerde \%3.85 (21), erkek öğrencilerde 
\%7.33'dür (40). Erkek öğrencilerin çizimlerinde büyük çoğunluğun (\%49) mühendisi erkek olarak çizdiği, kadın olarak çizseler bile tek başına çizimlerde kadın mühendise yer vermedikleri görülmektedir. Tüm sınıf düzeyleri değerlendirildiğinde kadın bilim insanı çizimlerinde sinıf düzeylerine göre belirgin bir artma ya da azalma gözlenmemektedir. Bilim insanını kadın olarak çizenlerde beşinci ve altıncı sınıf öğrencilerinden \%2, yedinci sınıf öğrencilerinden ise \%3 oranındadır. Ayrıca sınıf düzeyi artıkça erkek bilim insanı çizme oranının arttığı da gözlenmektedir. Beşinci sınıf öğrencilerinin \%14'ü, altıncı sınıf öğrencilerinin \%19'u ve yedinci sınıf öğrencilerinin \%40'1 bilim insanını erkek olarak çizmişlerdir.

İnsan figürünün olmadiğı çizimlerde deney tüpleri, deney malzemeleri ön plana çıkmaktadır. Şekil 1'de insan figürünün olmadığı bilim insanı algısını anlatan çizimlere yer verilmiştir.

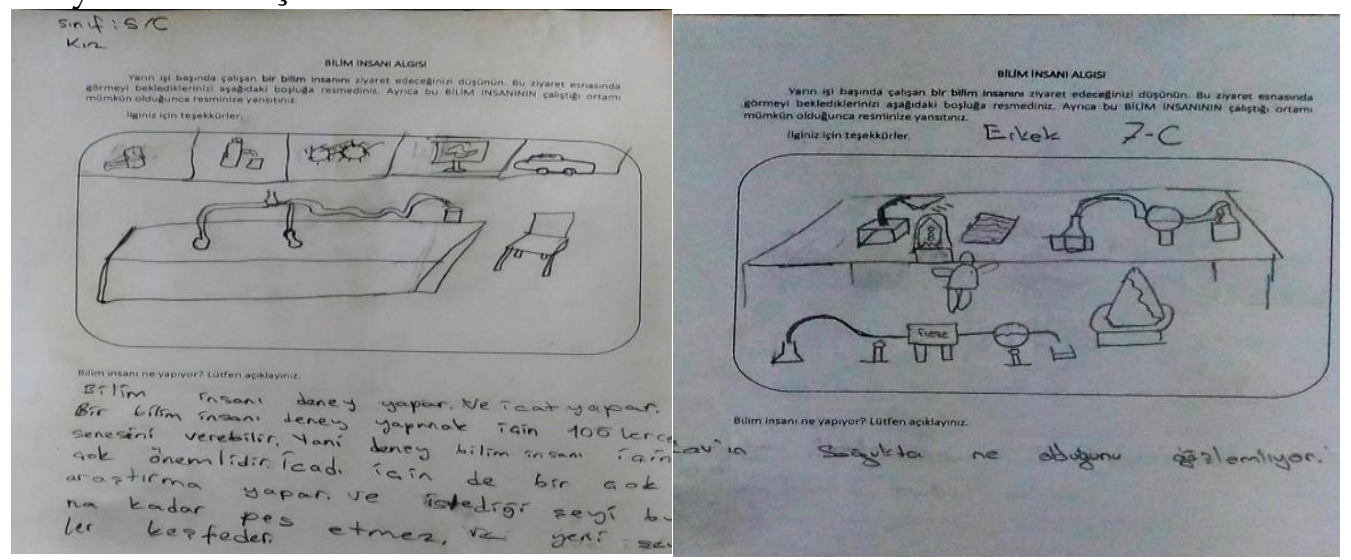

Şekil 1. İnsan figürü olmayan çizim örnekleri

Şekil 1'de yer alan çizimde de görüldüğü gibi öğrenci çizimlerinde insan figürü olmayan çizimlere de rastlanmamıştır. İnsan figürü olmayan çizimler de ortamda deney araç gereçlerine, formüllere, kitaplara yer verilmiştir. Öğrenci çizimlerinde bilim insanını kadın olarak çizenler daha çok kız öğrenciler olmuştur. Şekil 2'de kız ve erkek öğrencilere ait bilim insanı algısı çizimlerine yer verilmiştir.
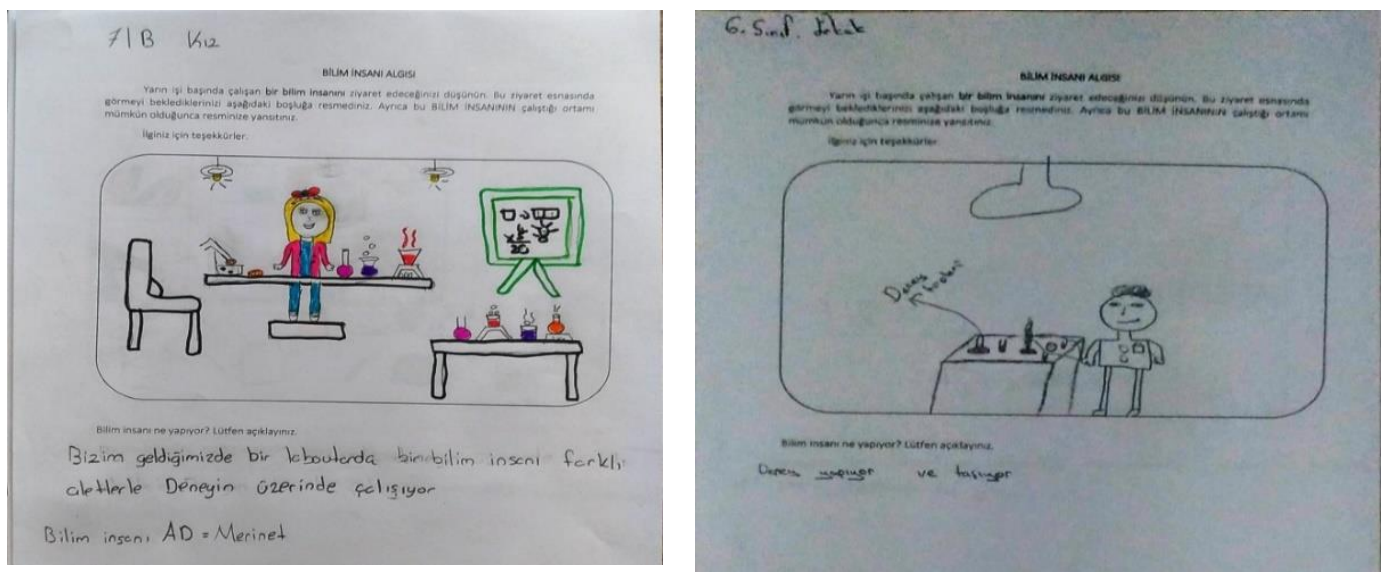

Şekil 2. Kadın ve erkek bilim insanına ilişkin çizim örnekleri

Şekil 2'de farklı sınıf düzeylerinde bulunan kız ve erkek öğrencilere ait bilim insanı algısına verdikleri çizimleri ve yanıtları yer almaktadır. Kız öğrenci bilim 
insanını kadın olarak çizmişken erkek öğrenci ise bilim insanının cinsiyetini erkek olarak çizmiştir.

\section{Bilim İnsanının Çalışma Alanı}

Bilim insanı çizimlerinde elde edilen bilim insanının çalışma alanlarının cinsiyet ve sınıflara göre frekans ve yüzde dağılımları Tablo 4'de verilmiştir.

Tablo 4

Bilim İnsanı Çizimlerinde Elde Edilen Bilim İnsanının Çalışma Alanlarının Cinsiyet ve Sınıflara Göre Frekans ve Yüzde Dağılımları

\begin{tabular}{llllllll}
\hline Ortam türü & & $\mathrm{K} 1 \mathrm{z}$ & Erkek & 5.sınıf & 6. sınıf & 7. sınıf & Toplam \\
\hline Laboratuvar & $\mathrm{f}$ & 220 & 215 & 55 & 98 & 129 & 282 \\
& $\%$ & 40.36 & 39.44 & 10.09 & 17.98 & 23.66 & 79.81 \\
Oda/ofis & $\mathrm{f}$ & 35 & 18 & 8 & 6 & 39 & 53 \\
& $\%$ & 6.42 & 3.30 & 1.46 & 1.10 & 7.15 & 9.72 \\
Kütüphane & $\mathrm{f}$ & 14 & 4 & 2 & 6 & 10 & 18 \\
& $\%$ & 2.56 & 0.73 & 0.36 & 1.10 & 1.83 & 3.30 \\
Doğal ortam & $\mathrm{f}$ & 16 & 23 & 10 & 13 & 16 & 39 \\
(doğa, bahçe) & $\%$ & 2.93 & 4.22 & 1.83 & 2.38 & 2.93 & 7.15 \\
\hline
\end{tabular}

Tablo 4 incelendiğinde kız ve erkek öğrencilerin de bilim insanının çalışma ortamı olarak en fazla laboratuvar resmi çizdikleri görülmektedir. Laboratuvar çizimleri toplam çizimlerin \%79.81'ini oluşturmaktadır. K1z öğrencilerin \%40.36's1 (220), erkek öğrencilerin ise \%39.44'ü (215) bilim insanlarını laboratuvar ortamında göstermişlerdir. Bilim insanının çalışma ortamını oda veya ofis şeklindeki çizimler tüm çizimlerin \%9.72'sini oluşturmaktadır. K1z öğrencilerin \%6.42'si erkek öğrencilerin ise \%3.30'u bilim insanının çalışma ortam türünü oda/ofis olarak çizmiştir. Çalışma ortamını kütüphane olarak çizenler \%3.30'dur. Kütüphane ortamında bilim insanının çalıştığını belirtenlerden \%2.56'sını k1z öğrenciler, \% 0.73'ünü erkek öğrenciler oluşturmaktadır. \%7.15 oranında bilim insanının bahçe, doğa gibi alanlarda çalıştığını çizen öğrenciler bulunmaktadır. Doğa, bahçe gibi açık alanda çalıştığını belirten çizimlerin \%2.93'ünü kız öğrenciler, \%4.22'sini erkek öğrenciler oluşturmuştur.

Katılımcıların sınıf dağılımı düşünüldüğünde öğrencilerin sınıf düzeyi temel alındığında yapılan değerlendirmede benzer bir sonuç ortaya çıkmaktadır. Çalışma ortamının laboratuvar olduğuna dair beşinci sınıf öğrencilerinden \%10, altıncı sınıf öğrencilerinden \%17 ve yedinci sınıf öğrencilerinin de \%23'ünün çizim yaptığ1 görülmektedir. Sınıf düzeyi artıkça laboratuvar çizimlerinin artığı söylenebilir. Çalışmaya katılan öğrencilerin \%79.81'i çizimlerinde bilim insanı laboratuvar ortamında göstermiştir. Oda/ofis ve doğal ortam da diğer ön plana çıkan çalışma alanlarıdır. Beşinci sınıf öğrencilerinden \%1.46'sı, altıncı sınıf öğrencilerinden \%1.10'u ve yedinci sınıf öğrencilerinden \%7.15'i bilim insanının çalışma ortam türünü oda, ofis gibi ortamda çizmiştir. Çalışmaya katılan öğrencilerin \%9,72'si (53) bilim insanını oda/ofiste, \%7.15'i (39) öğrenci ise doğal ortamda (doğa, bahçe) çizmişlerdir. Bilim insanının çalışma ortam türünü doğada, bahçede çizenlerin \% 0.36 'sını beşinci sınıf, \%1.10'ini altıncı sınıf ve \%3.30'unu yedinci sınıf öğrencileri oluşturmaktadır. Öğrencilerin \%3.30'ü (18) bilim insanının çalışma ortamı olarak kütüphaneyi 
çizmiştir. Kütüphane çizenlerin oranı diğer ortam türlerine göre en az orana sahiptir. Bilim insanının çalışma ortam türünü kütüphane olarak çizenlerin \%0.36'sı beşinci, $\% 1.10^{\prime}$ u altıncı ve \%1.83'ü yedinci sınıf öğrencilerine ait çizimlerdir. Farklı ortam türlerinde çalışan bilim insanları çizimleri örneği Şekil 3’ de gösterilmiştir.

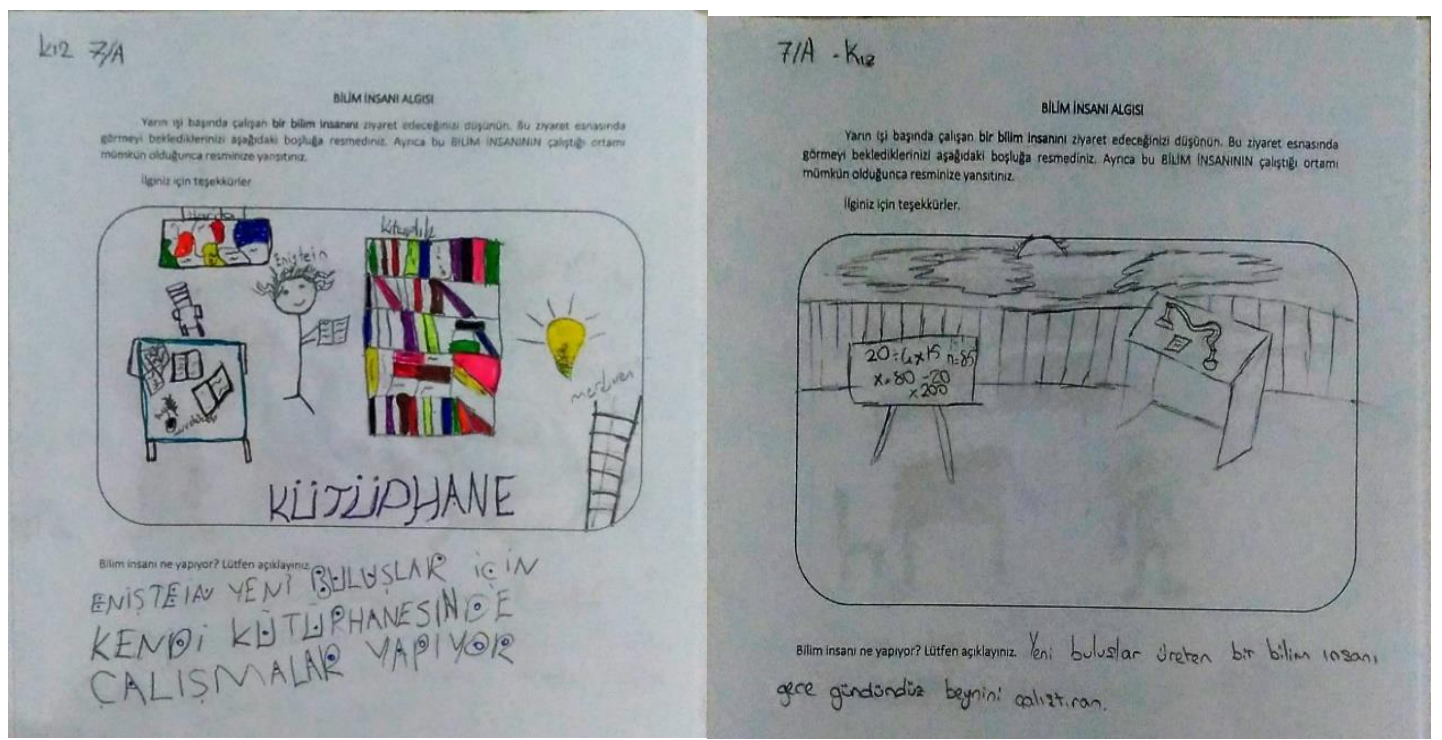

Şekil 3. Bilim insanının çalışma alanına ait çizim örnekleri

Şekil 3'de bilim insanına ait öğrencilerin örnek çizimlerinde kütüphane ortamında ve doğada çalışan bilim insanı yer almaktadır.

\section{Bilim İnsanının Çalışma Ortamında Bulunan Araç-Gereç ve Eşyalar}

Katılımcıların Bilim İnsanı Çiz testinde bilim insanının çalışma ortamında bulunan araç gereçler ve eşyalar ile ilgili bulgular Tablo 5'de verilmiştir. Bu bulgular hem cinsiyet hem de sınıf değişkenlerine göre frekans ve yüzde dağılımı olarak tabloda sunulmuştur.

Tablo 5

Öğrencilerin Sınıf ve Cinsiyetine Göre Bilim İnsanı Çiz Testinde Ortamın Araç-Gereç ve Eşyalarının Frekans ve Yüzde Dă̆ıllımları

\begin{tabular}{llllllll}
\hline $\begin{array}{l}\text { Ortamın araç-gereç } \\
\text { ve eşyaları }\end{array}$ & & $\mathrm{K} ı \mathrm{z}$ & Erkek & 5.sinıf & 6. sinıf & 7. sinıf & Toplam \\
\hline Deney tüpleri & $\mathrm{f}$ & 163 & 149 & 64 & 109 & 139 & 312 \\
& $\%$ & 29.90 & 27.33 & 11.74 & 20 & 25.50 & 57.24 \\
Formüller, çizimler & $\mathrm{f}$ & 18 & 22 & 3 & 13 & 24 & 40 \\
& $\%$ & 3.30 & 4.03 & 0.55 & 2.38 & 4.40 & 7.33 \\
Kitaplar & $\mathrm{f}$ & 60 & 30 & 4 & 44 & 42 & 90 \\
& $\%$ & 11.00 & 5.50 & 0.73 & 8.07 & 7.70 & 16.51 \\
Mikroskop, & $\mathrm{f}$ & 42 & 31 & 12 & 17 & 44 & 73 \\
teleskop & $\%$ & 7.70 & 5.68 & 2.20 & 3.11 & 8.07 & 13.39 \\
Büro malzemeleri & $\mathrm{f}$ & 81 & 75 & 60 & 47 & 49 & 156 \\
& $\%$ & 14.86 & 13.76 & 11.00 & 8.62 & 8.99 & 28.62 \\
\hline
\end{tabular}


Tablo 5 incelendiğinde, öğrencilerin çizimlerinde en fazla deney tüpü (\%57.24) çizdikleri görülmüştür. Deney tüpü çizenlerin \%29.90'1nı k1z öğrenciler, \%27.33'ünü erkek öğrenciler oluşturmuştur. Sınıf düzeyine göre bakıldığında ise \%11.74'ünü beşinci, \%20'sini altıncı ve \%25.50'sini yedinci sınıf öğrencileri oluşturmaktadır. Bunun yanında teleskop, mikroskop, kitap formül ve büro malzemelerine yer verdikleri gözlemlenmiştir. Kız ve erkek öğrencilerin çizimlerinde deney tüpü, formüller ve büro malzemesine yer verme oranlarının yakın olduğu görülmektedir. Fakat kitap çizme noktasında kız öğrencilerin (\%11), erkek öğrencilerden (\%5) daha fazla yer verdiği görülmektedir. Ayrıca sınıf düzeyi artıkça çizimlerde yer verilen büro malzemelerinin çizim oranının düştüğü ama deney tüpleri ve formüllerin oranının arttığı da görülmektedir. Çizimlerinde büro malzemesini kullananlardan \%11'ini beşinci, \%8.62' sini altıncı, \%8.99'unu yedinci sınıf öğrencileri oluşturmuştur.

K1z öğrencilerin \%7.70'i, erkek öğrencilerin \%5.68'si bilim insanı alg1sı çizimlerinde mikroskop ve teleskopa yer vermiştir. Mikroskop ve teleskop gibi araç gereçlerin sınıf düzeyi artıkça çizimlerde de artığı diğer bir sonuçtur. Öğrencilerin çizimlerinden beşinci sınıfların \%2.20'si, altıncı sınıfların \%3.11'i, yedinci sınıfların \% 8.07'sının çizimlerinde teleskop ve mikroskopa yer verdiği görülmektedir. Teleskop ve mikroskop çizen öğrenciler genelde ikiside aynı kağıt üzerinde resmettiği için tabloda da birlikte verilmiştir. Çizimler sonucunda yapılan temalaştırmada çizilen mikroskop ve teleskop sayılarının birbirine çok yakın olduğu görülmüştür. Teleskop ve mikroskobun birlikte yer aldığı örnek resim Şekil 4'de sunulmuştur.

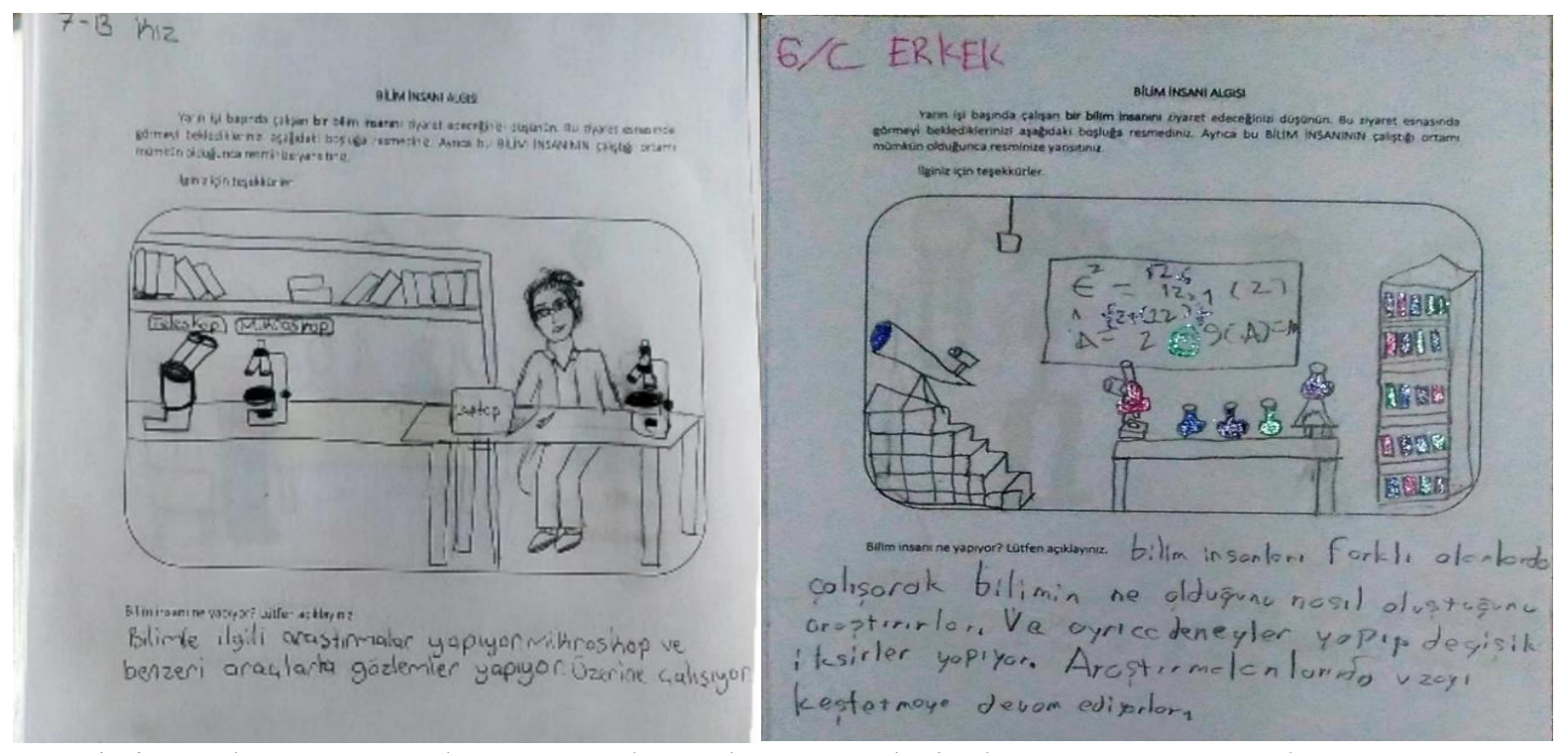

Şekil 4. Bilim insanı algısı çizimlerinde ortamda bulunan araç-gereçlere ait çizim örnekleri

Şekil 4 incelendiğinde ilk örnekte çalışma yapan bilim insanı, ikinci örnekte ise ortam araç gereçlerinde; teleskop, mikroskop, bilgisayar, kitap bulunmaktadır.

\section{İkinci Alt Probleme İlişkin Bulgular}

'Mühendis Çiz testine göre mühendisin cinsiyeti, çalışma alanı/ortamı, çalışma malzemeleri değişkenleri bakımından ortaokul öğrencilerinin cinsiyet ve sınıf düzeyi dağılımları nasıldır?' Problem sorusuna ilişkin cevap niteliğinde bulgular aşağıda 
verilmiştir. Bu amaçla Mühendis Çiz testinden elde edilen tüm veriler düzenlenmiş ve analiz edilmiştir.

\section{Öğrencilerin 'Mühendis Çiz' Testinde Elde Edilen Bulgular}

Öğrencilerin Mühendis Çiz testinden elde edilen bulgulara göre mühendisin cinsiyetine, çalışma ortamına, çalışırken tek mi birden fazla kişi ile mi çalıştığına, yaptığı işe ve branşına göre kız ve erkek öğrencilerin cevapları ve sınıf düzeyleri açısından cevapları frekans ve yüzde olarak aşağıda tablolarda belirtilmiştir.

\section{Mühendisin Cinsiyeti}

Katılımcıların mühendis çizerken belirttikleri cinsiyet ve yine çizdikleri mühendisin birlikte çalışma durumuna ilişkin veriler tablo aşağıda Tablo 6' da verilmiştir.

Tablo 6

Çizilen Mühendisin Cinsiyetine ve Birlikte Çalışma Durumuna İlişkin Bulgular

\begin{tabular}{|c|c|c|c|c|c|c|c|}
\hline \multicolumn{2}{|l|}{ Mühendis } & $\mathrm{K}_{1 \mathrm{Z}}$ & Erkek & 5.sinif & 6.sinif & 7.sinif & Toplam \\
\hline Erkek & $f$ & 170 & 228 & 96 & 118 & 184 & 398 \\
\hline & $\%$ & 32.62 & 43.76 & 18.42 & 22.64 & 35.31 & 76.39 \\
\hline Kadın & $\mathrm{f}$ & 52 & 9 & 19 & 18 & 24 & 61 \\
\hline & $\%$ & 10.08 & 1.72 & 3.64 & 3.45 & 4.60 & 11.70 \\
\hline Tek başına & f & 39 & 31 & 33 & 17 & 20 & 70 \\
\hline & $\%$ & 7.48 & 5.95 & 6.33 & 3.26 & 3.83 & 13.43 \\
\hline Birden fazla & f & 37 & 60 & 31 & 32 & 34 & 97 \\
\hline kişi ile & $\%$ & 7.17 & 11.63 & 5.95 & 6.14 & 6.52 & 18.61 \\
\hline
\end{tabular}

Tablo 6'daki verilere göre ortaokul öğrencileri çizdikleri resimde mühendisi \%76.39’u (398) erkek olarak çizerken, \%11.70’i (61) kadın olarak çizmişlerdir. Mühendisi erkek olarak çizenlerin \%32'sini (170) kız öğrenciler, \%43'ünü (228) erkek öğrenciler oluşturmaktadır. Kız öğrenciler mühendisin tek başına çalıştığı yönünde çizimlere ağırlık verirken, erkek öğrenciler mühendisin birden fazla kişi ile çalıştığ1 yönünde çizimlerine yer vermişlerdir. Kız öğrencilerde mühendisin tek başına çalışma oranı \%7.48 (39) iken birlikte çalışan mühendis çizme oranı \%7.17 (37) olarak görülmektedir. Erkek öğrencilerde mühendisi tek başına çalışıyorken çizenler \%5.95 (31) iken birlikte çalışan mühendis çizinler \%11.63' dür (60).

Veriler incelendiğinde özelikle mühendisin cinsiyetinin erkek olması gerektiği yönünde öğrencilerin düşünceleri yer almaktadır. Erkek mühendis çizim oranlarının sınıf düzeyine göre dağılımına bakıldığında \%18'i beşinci, \%22'si altıncı ve \%35'i yedindi sınıf öğrencilerine aittir. Kadın mühendis çizme oranı kızlarda \%10 iken erkek öğrencilerde \%1 şeklinde gözlenmiştir. Sınıf düzeyi arttıkça erkek mühendis çizimlerinin arttığını görmekteyiz. Mühendisi kadın olarak beşinci ve altıncı sınıf öğrencilerinden \%3'ü, yedinci sınıf öğrencilerinden \%4'ü bu yönde çizim yapmıştır. Mühendisi çalışırken tek başına çizenler beşinci sınıfta \%6 iken altıncı ve yedinci sınıf öğrencilerinin oranı \%3’dür. Mühendisi kadın olarak genelde kız öğrencilerin çizdiği tespit edilmiştir. Kız öğrencilere ait mühendis algısı çizimine ilişkin örneğe Şekil 5'te yer verilmiştir. 


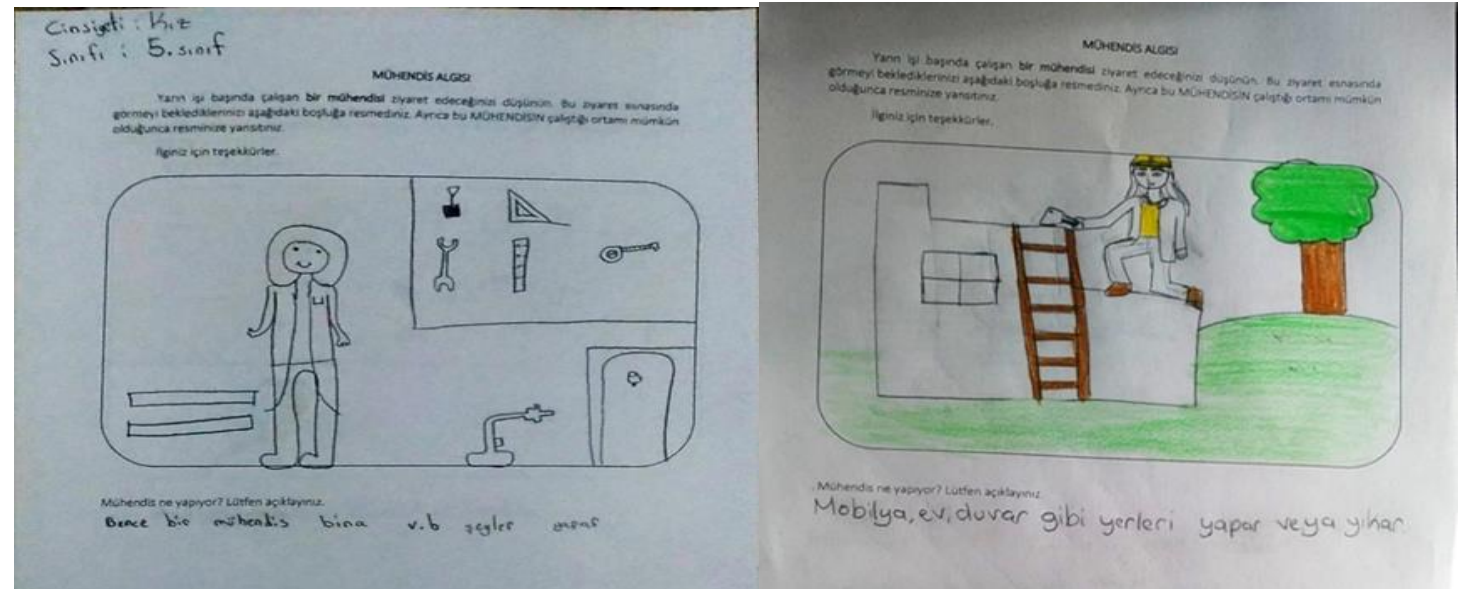

Şekil 5. K1z öğrencilere ait mühendis algısı çizim örnekleri

Şekil 5'de farklı sınıf seviyelerinde bulunan kız öğrencilerine ait mühendis algısı çizimleri gösterilmektedir. K1z öğrencilerin mühendis algısı çizimlerinde mühendisi kadın olarak çizdikleri görülmektedir. Erkek öğrencilere ait mühendis algısı çizim örneklerine Şekil 6'da yer verilmiştir.
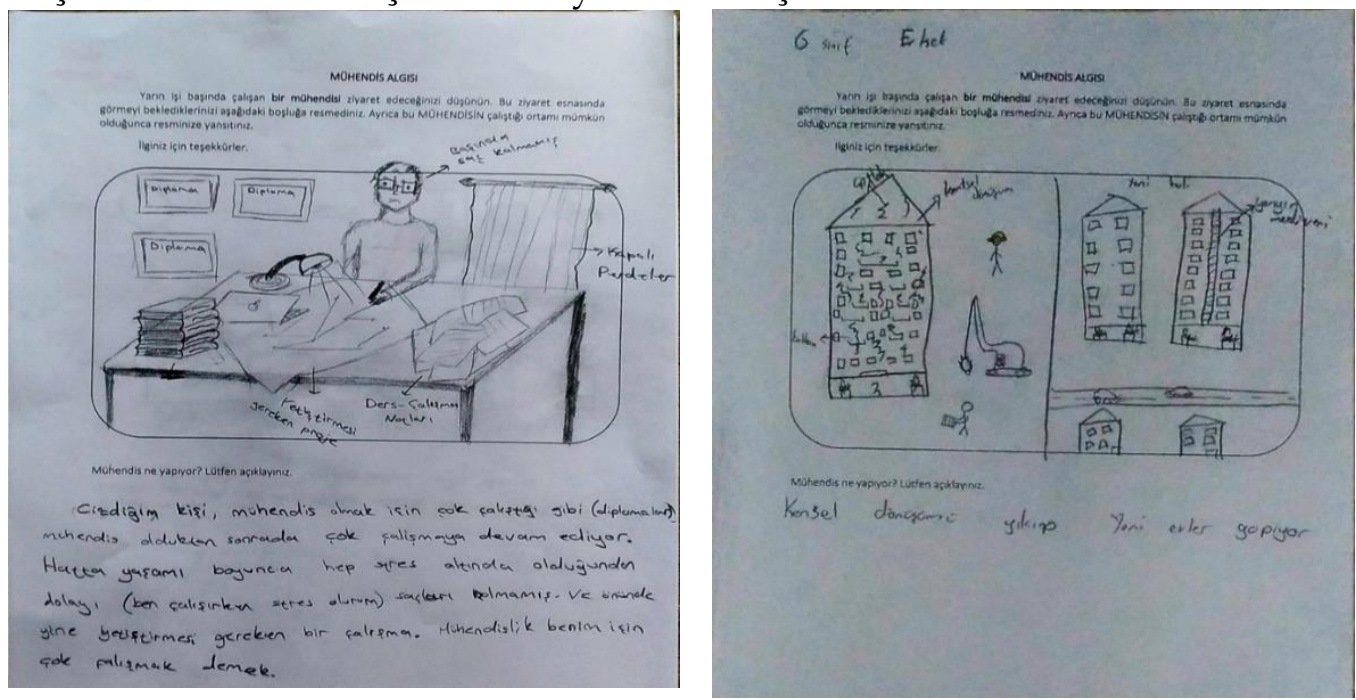

Şekil 6. Erkek öğrencilere ait mühendis algısı çizim örnekleri

Şekil 6'da erkek öğrencilere ait mühendis algısı çizimleri gösterilmektedir. Erkek öğrencilerin mühendisi erkek olarak çizdikleri görülmektedir.

\section{Mühendisin Çalışma Ortamı}

Mühendisin çalışma ortamı ile ilgili cevap veren toplam öğrenci sayısı 324 kişiden oluşmaktadır. 197 öğrenci mühendisin çalışma ortamı hakkında belirli bir yer belirtmemiştir. Katılımcların Mühendis Çiz testinden elde edilen bulgulardan mühendisin çalışma ortamlarının cinsiyet ve sınıflara göre frekans ve yüzde dağılımları Tablo 7' de verilmiştir. 
Tablo 7

Mühendis Çizimlerinde Elde Edilen Mühendisin Çalışma Ortamlarnnn Cinsiyet ve Sinıflara Göre Frekans ve Yüzde Dă̆̆lımları

\begin{tabular}{|c|c|c|c|c|c|c|c|}
\hline Çalışma ortamı & & $\mathrm{K}_{1 \mathrm{Z}}$ & Erkek & 5.sinif & 6.sinif & 7. sinif & Toplam \\
\hline \multirow{2}{*}{$\begin{array}{l}\text { Açık alan (park, yol, } \\
\text { inşaat) }\end{array}$} & $\mathrm{f}$ & 75 & 80 & 52 & 38 & 65 & 155 \\
\hline & $\%$ & 23.14 & 24.69 & 16.04 & 11.72 & 20.06 & 47.83 \\
\hline \multirow{2}{*}{$\begin{array}{l}\text { Kapalı alan (masa } \\
\text { başında, oda, ofis) }\end{array}$} & $\mathrm{f}$ & 79 & 90 & 49 & 50 & 70 & 169 \\
\hline & $\%$ & 24.38 & 27.77 & 15.12 & 15.43 & 21.60 & 52.16 \\
\hline
\end{tabular}

Tablo 7'ye göre öğrencilerin çizimlerinde mühendisin çalışma ortamına ilişkin birbirine yakın cevaplar verdiklerini az bir farkla da olsa masa başında çalışan mühendise verdikleri yanıtların fazla olduğu görülmektedir. Açık alanda çalışan mühendis \%47.83 iken kapalı alanda çalışan mühendis oranı \%52.16 olarak hesaplanmıştır. Mühendisin çalışma ortamını açık alan olarak çizenlerin \%23'ü kız, \% 24'ünü erkek öğrenciler oluşturmaktadır. Çalışma ortamı olarak kapalı alan çizenlerin \%24'ünü k1z, \%27'sini erkek öğrenciler oluşturmaktadır. Mühendisin kapalı alanda çalıştığına dair düşüncelerin sınıf düzeyi ile birlikte arttığ1 görülmektedir. Beşinci sınıf öğrencilerinden \%15.12'si, altıncı sınıf öğrencilerinden \%15.43'ü ve yedinci sınıf öğrencilerinden \%21.60'1 mühendisin kapalı alanda çalıştığını çizmiştir. Öğrencilerin çizimlerinde mühendisi açık alanda çalışma durumları sinıf düzeyine göre incelendiğinde; beşinci sınıf öğrencilerinden \%16’s1, altınc1 sınıf öğrencilerinden \%11'i ve yedinci sınıf öğrencilerinden \%20'si şeklindedir. Kapalı alanda çalışan mühendis çizim örneklerini Şekil 7'de yer almaktadır.


Şekil 7. Kapalı alanda çalışan mühendise ilişkin çizim örnekleri

Şekil 7'deki çizimlerde masa başında ya da kapalı ortamda çalışan mühendise ilişkin örnekler yer almaktadır. Öğrenci çizimlerinde mühendisin açık alanda çalıştığına dair örnek Şekil 8'de verilmiştir. 


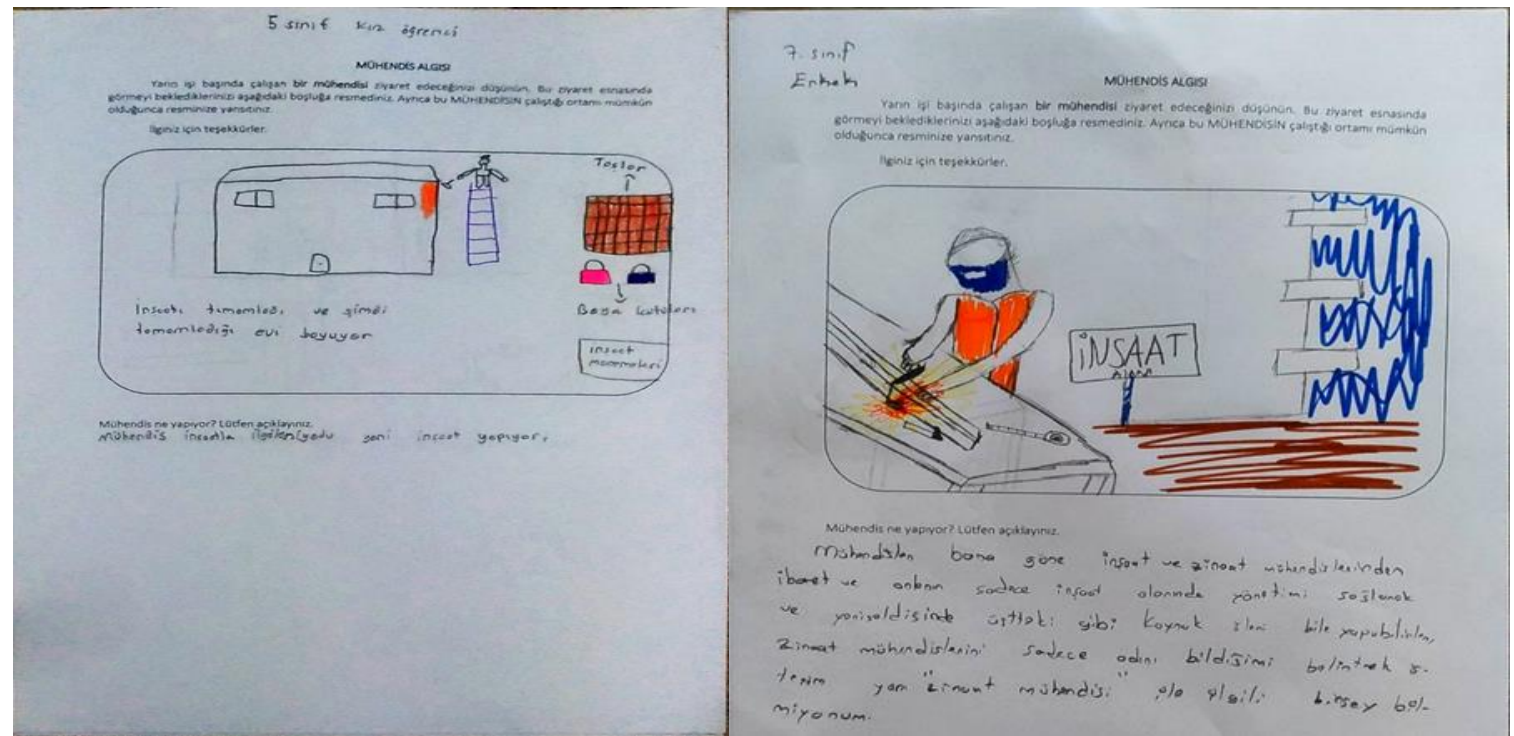

Şekil 8. Açık alanda çalışan mühendise ilişkin çizim örnekleri

Şekil 8'da mühendisin açık alanda çalıştığına dair öğrenci çizimi gösterilmiştir. Açık alanda çalışan mühendislerde inşaat sahası, park düzenleme, yol yapımı gibi çizimlerle ifade edilmiştir.

\section{Mühendisin Çalışma Alanı}

Mühendisin yaptığı iş ile ilgili bulgulara bakıldığında 521 öğrenciden 397 öğrencinin çizimlerinde yaptıkları iş ile ilgili veriler bulunmaktadır. Araştırmaya katılan 124 öğrenci, mühendisin yaptığı iş hakkında fikrini çizime yansıtmamıştır. Tablo 8'de mühendisin yaptığ1 iş hakkında bulgular frekans ve bu konuda katılım sağlayan öğrenciler açısından yüzde olarak verilmiştir. Tabloda mühendisin yaptığı iş ile ilgili bulgular cinsiyet ve sınıf değişkenlerine göre verilmiştir.

Tablo 8

Mühendis Çiz Testinde Elde Edilen Mühendisin Yaptığı İş İle İlgili / Çalışma Alanlarının Cinsiyet ve Sınıflara Göre Frekans ve Yüzde Dağılımı

\begin{tabular}{llllllll}
\hline Çalışma alanı & & Kız & Erkek & 5. sınıf & 6. sınıf & 7. sınıf & Toplam \\
\hline Bina yapar & $\mathrm{f}$ & 90 & 73 & 53 & 38 & 72 & 163 \\
& $\%$ & 22.67 & 18.38 & 13.35 & 9.57 & 18.13 & 41.05 \\
Proje çizer & $\mathrm{f}$ & 61 & 71 & 30 & 31 & 71 & 132 \\
& $\%$ & 15.36 & 17.88 & 7.55 & 7.80 & 17.88 & 33.24 \\
Denetler/kontrol eder & $\mathrm{f}$ & 12 & 26 & 3 & 13 & 22 & 38 \\
& $\%$ & 3.02 & 6.54 & 0.75 & 3.27 & 5.54 & 9.57 \\
Tamir eder & $\mathrm{f}$ & 10 & 19 & 6 & 11 & 12 & 29 \\
& $\%$ & 2.51 & 4.78 & 1.51 & 2.77 & 3.02 & 7.30 \\
Makine yapar & $\mathrm{f}$ & 9 & 13 & 2 & 2 & 18 & 22 \\
& $\%$ & 2.26 & 3.27 & 0.50 & 0.50 & 4.53 & 4.54 \\
Diğer(boya,ilaç,robot) & $\mathrm{f}$ & 7 & 6 & 6 & 6 & 1 & 13 \\
& $\%$ & 17.63 & 1.51 & 1.51 & 1.51 & 0.25 & 3.27 \\
\hline
\end{tabular}

Öğrencilerin çizimleri incelendiğinde mühendisin çalışma alanları açısından en çok öğrenciler mühendisin bina yaptığını (\%41.05) düşünmektedir. Bu oran 
mühendisin yaptığ 1 iş ile ilgili verilen cevaplar arasında yarıya en yakın olan cevaptır. Diğer cevaplar; proje çizimi yapar $(\% 33,24)$, denetler/ kontrol eder $(\% 9.57)$, tamir eder (\%7.30) ve makine yapar (\%5.54) şeklindedir. Cevapların (\%3.27) ise içerisinde boya yapar, deney yapar, robot yapar ve ilaç yapar gibi ifadeler yer almaktadır Kız öğrencilerin \%22'si mühendisi bina yapar, \%15'i proje çizer, \%3'ü denetler, \%2'si makine yapar tamir eder ve \%17'si robot yapar, boyama yapar veya ilaç yapar şeklinde ifade etmiştir. Mühendisin yaptığ 1 iş ile ilgili erkek öğrencilerden \%18'i bina yapar, \%17'si proje çizer, \%6'sı denetler, \%4'ü tamir eder, \%3'ü makine yapar ve \%1'i boya yapar, ilaç yapar veya robot yapar şeklinde ifade etmiştir. Şekil 9' da öğrencilerin çizim örnekleri yer almaktadır.
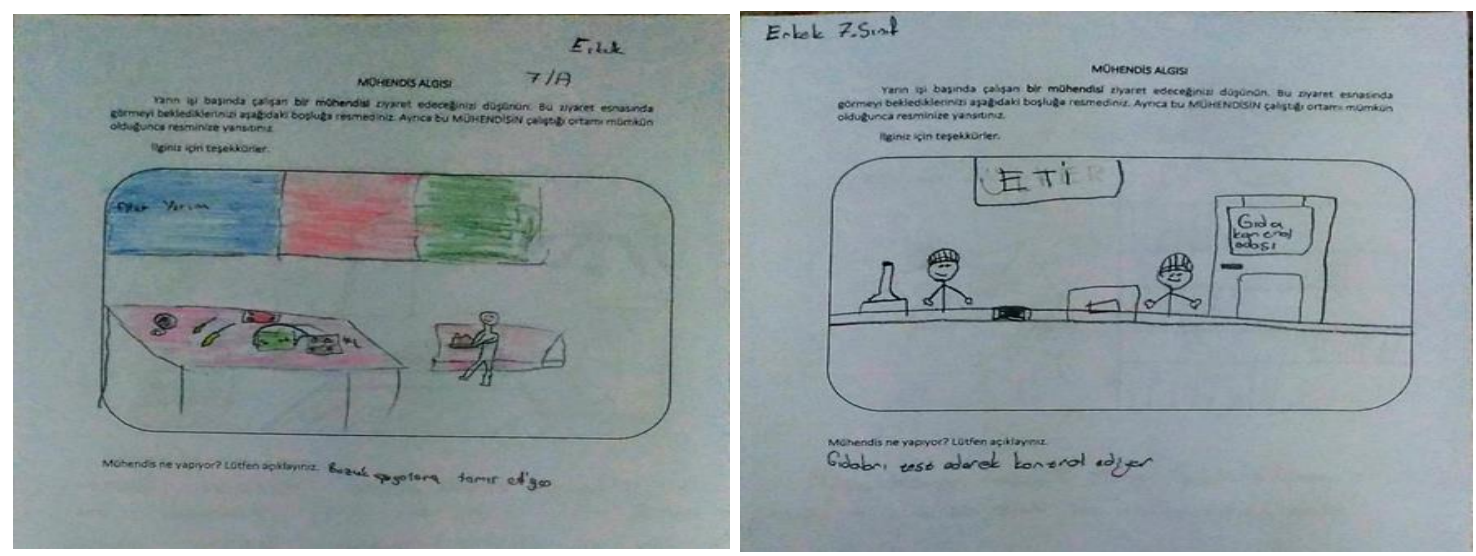

Şekil 9. Mühendisin yaptığı işi ifade eden çizim örnekleri

Şekil 9'da bir öğrencinin çizdiği mühendisin ne yaptığına dair sorulan soruya cevap olarak tamir etmek olduğu görülmekte, mühendislerin fabrika, inşaat gibi alanlarda çalışmaları resmedilmektedir.

\section{Mühendisin Branşı}

Öğrenci çizimlerinden yapılan analizler sonucunda, öğrencilerin çizdikleri mühendisin branşına yönelik yaptıkları yorumlar ve çizimler tablo halinde verilmiştir. Tablo 9'da öğrencilerin çizdikleri mühendise ait bulgular frekans ve yüzde olarak yer almaktadır.

Tablo 9

Mühendisin Branşına İlişkin Bulgular

\begin{tabular}{llllllll}
\hline Branş & & $\mathrm{K} 1 \mathrm{z}$ & Erkek & 5.sınıf & 6. sınıf & 7. sinıf & Toplam \\
\hline İnşaat & $\mathrm{f}$ & 62 & 47 & 44 & 31 & 34 & 109 \\
& $\%$ & 24.89 & 18.87 & 17.67 & 12.44 & 13.65 & 31.23 \\
Bilgisayar & $\mathrm{f}$ & 41 & 22 & 28 & 22 & 13 & 63 \\
& $\%$ & 16.46 & 8.83 & 11.24 & 8.83 & 5.22 & 25.30 \\
Elektrik & $\mathrm{f}$ & 11 & 10 & 4 & 9 & 8 & 21 \\
& $\%$ & 4.41 & 4.01 & 1.60 & 3.61 & 3.21 & 8.43 \\
Makine & $\mathrm{f}$ & 7 & 14 & 7 & 4 & 10 & 21 \\
& $\%$ & 2.81 & 5.62 & 2.81 & 1.60 & 4.01 & 8.43 \\
Ziraat & $\mathrm{f}$ & 11 & 2 & 4 & 3 & 6 & 13 \\
& $\%$ & 4.41 & 0.80 & 1.60 & 1.20 & 2.40 & 5.22 \\
Diğer & $\mathrm{f}$ & 9 & 12 & 8 & 3 & 10 & 21 \\
& $\%$ & 3.61 & 4.81 & 3.21 & 1.20 & 4.01 & 8.43 \\
\hline
\end{tabular}


Mühendisin branşına ait bilgiler incelendiğinde hem kız öğrencilerin hem de erkek öğrencilerin en fazla inşaat mühendisi (\%31) çizdikleri gözlenmiştir. Daha sonra onu takip eden bilgisayar mühendisi (\%25) gelmektedir. Çizimlerde yine branş olarak elektrik mühendisinin, makine mühendisinin, ziraat mühendisinin de yer aldığ1 görülmektedir. Sınıflar arasında mühendisin branşına ilişkin belirgin bir farklılaşma göze çarpmamaktadır. Araştırmamızda mühendis algısından yola çıkarak öğrencilerin vermiş oldukları cevaplara bakarak çizdikleri mühendisin branşına ilişkin bulgular incelendiğinde, k1z öğrencilerin \%24'ü inşaat, \%16'sı bilgisayar, \%4'ü elektrik ve ziraat, \%2'si makine mühendisi ve \%3'ü diğer mühendislikleri çizdiğini yazmıştır. Erkek öğrencilerden \%18'i inşaat, \%8'i bilgisayar, \%5'i makine, \%4'ü elektrik mühendisini çizimlerine yansıtmış ve bu şekilde açıklamışlardır. Sınıf düzeyinde öğrencilerin çizdikleri mühendisin branşı hakkındaki açıklamalarına bakıldığında beşinci sınıf öğrencilerinden \%17'si inşaat, \%11'bilgisayar, \%3'ü diğer, $\% 2$ 'si makine, \%1elektrik ve ziraat mühendisi çizmiştir. Altıncı sınıf öğrencilerinden $\% 12$ 'si inşaat, \%8'i bilgisayar, \%3 elektrik ve \%1 oranlarında makine, ziraat ve diğer branşlara ait çizimler ve açılamalar yapmışlardır. Yedinci sınıf öğrencilerinin mühendisin branşına dair yaptıkları çizimlerin oranlarında ise \%13'ü inşaat, \%5'i bilgisayar, \%4'ü makine, \%3'ü elektrik ve \%4'ü diğger branşlara ait mühendisliklere rastlanmaktadır. Şekil 10' da mühendisin branşına ait yorum içeren bir öğrenci çizimi gösterilmiştir.
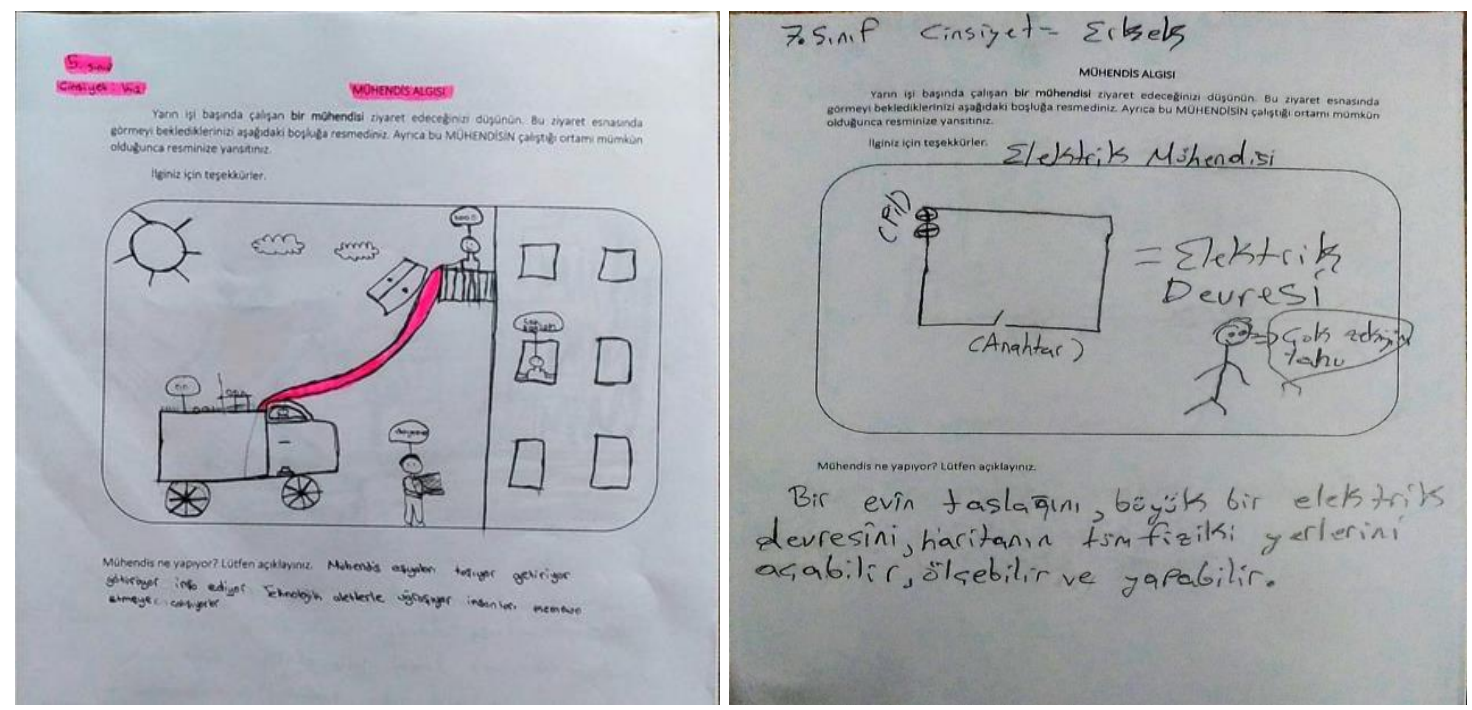

Şekil 10. Mühendisin branşına ait çizim örnekleri

Şekil 10'da altıncı ve yedinci sınıfta öğrenim gören öğrencilere ait mühendis algısı çizimini ve çizdiği mühendisin ne yaptığı hakkında yaptığı yorumu yer almaktadır. Öğrenci çizimindeki mühendisin ne yaptığı ile ilgili soruya verdiği cevapta mühendisin branşı hakkında da ifadelerini belirtmiştir. Öğrenci yorumuna bakarak burada çizilen mühendislerden birinin bilgisayar diğerinin ise elektrik mühendisi olduğunu görülmektedir. 


\section{Tartışma, Sonuç ve Öneriler}

Çalışmada ilk olarak ortaokul öğrencilerinin bilim insanı algıları incelenmiştir. Öğrencilerin vermiş oldukları cevaplarda bilim insanını, cinsiyet olarak erkek resmettikleri, çalışma ortamlarının daha çok laboratuvar ortamı olduğu ve çizilen resimlerde daha çok (\%70.6) laboratuvar malzemeleri tercih ettikleri gözlenmiştir. Öğrenciler üzerinde yapılan bu araştırmada daha çok bilim insanının kalıp yargılar içerisinde değerlendirildiği görülmektedir. Bu durum daha önce yapılan çalışmalarla benzerlik göstermektedir (A ğgül, Yalçın, 2012; Chambers, 1983; Çermik, 2013; Kara, 2013; Kaya, Doğan ve Öcal, 2008; Kemaneci, 2012; Keser, 2012; Kibar Kavak, 2008; Küçük ve Bağ, 2012; Medina Jerez, Middleton ve Orihuela Rabaza, 2011; McDuffie, 2001; Nuhoğlu ve Afacan, 2011; Özsoy ve Ahi, 2014; Ruiz Mallen ve Escalas, 2012; Toğrol, 2013; Türkmen, 2008).

Bilim insanı cinsiyetini çizerken erkek ve kız öğrencilerin çoğunun (\%74.49) erkek bilim insanı çizdiği görülmüştür. Yapılan bu çalışmalardan farklı olarak bilim insanının hem kadın hem erkek olabileceği sonucuna ulaşan analizler de mevcuttur. Bağ (2013), dördüncü ve beşinci sınıf öğrencileri ile gerçekleştirdiği çalışmasında öğrencilerde bilim insanının hem kadın hem de erkek olabileceğine dair çizimlere rastlamıştır. Bu sonucu ise değişen eğitim programlarına ve eğitim kurumlarının bilim insanının cinsiyeti konusunda bilinç kazanmasına bağlamıştır. Ayrıca benzer olarak bu çalışmada da bilim insanı cinsiyetinin kadın olarak belirtildiği çizimlerinde en çok kız öğrenciler tarafından yapıldığı görülmüştür. Daha önce yapılan çalışmalara bakıldığında da kız öğrencilerin çizimlerinde tercihen kadın bilim insanı çizdiklerine rastlanmıştır (Ağgül ve Yalçın, 2012; Chambers, 1983; Kibar ve Kavak, 2008; Korkmaz ve Kavak, 2010). Erkek öğrencilerin bilim insanı cinsiyeti konusunda daha gelenekselci olduğu söylenebilir. Bu durum Ruiz, Mallen ve Escalas (2012)'in 6-17 yaş aralığındaki 314 öğrencinin bilim insanı görüşlerini incelediği çalışması ile benzerlik göstermektedir. Öğrencilerin yazılı, görsel, sosyal medya ve ders kitaplarında "bilim adamı" kavramı ile karşılaşması çalışmada elde edilen bu sonucu açıklayabilir.

Çalışmada elde edilen sonuçlara benzer şekilde, Çakıcı (2018) farklı öğretim kademesindeki öğrencilerle yapmış olduğu çalışmada, anaokulu ve ilkokul öğrencilerinde bilim insanı algılarının çeşitlilik gösterdiği fakat sınıf seviyesinin artıkça bilim insanı algısının kalıplaştığını görmüş̧tür. Öğrencilerde bilim insanı algısı ile eğitim düzeyi değişim göstermiştir. Öğrenciler tarafından çizilen bilim insanlarının çoğunun erkek olarak hayal ettikleri sonucu Toğrol'un (2000) çalışması ile benzerlik göstermektedir. Toğrol (2000), ilköğretim ve lise düzeyinde öğrencilerle çalışmış ve 443 kişiye DAST ölçeği uygulamıştır. Araştırma sonucunda örneklemin \%72.5'i bilim insanının çiziminde cinsiyet olarak erkek, \%12.6'sı ise kadın olabileceğini çizmişlerdir. Ayrıca çizimlerde yer alan diğer bir ayrıntı da kitap çizimleri olmuştur. Benzer şekilde, Gülhan ve Şahin'in (2018) ortaokul öğrencilerinin bilim insanı ve mühendis algılarına yönelik yapmış oldukları çalışmada beşinci ve yedinci sınıf öğrencilerinin bu konudaki düşüncelerinden yola çıkarak içerik analizinde bulunmuşlardır. Bağımlı değişken olarak bilim insanı algısı ve mühendis algılarına bakılmıştır. Öğrencilerin hayallerindeki bilim insanı ve mühendisleri çizmeleri istenmiştir. Araştırma sonucunda özellikle kız öğrencilerin sınıf düzeyi arttıkça kadın mühendis ve bilim insanı algısının azaldığına ulaşılmıştır. Bu sonuç kız öğrencilerin meslek kariyer 
seçimi açısından oldukça dikkat çekicidir. Bu sonuçlar ışığında, çözüm olarak etkili bir STEM eğitimi önerilebilir.

Bilim insanının çalışma ortamı olarak da çoğunluğun (\%79.81) laboratuvarı tercih ettikleri görülmüştür. Çizimlerde dikkat çeken bir diğer unsur da çalışma ortamında kitap, deney tüpü, mikroskop, teleskop gibi eşyaların da yer alması olmuştur. Çalışma verileri incelendiğinde kız ve erkek öğrencilerin de bilim insanının çalışma ortamı olarak en fazla laboratuvar resmi çizdikleri görülmektedir. Bu durumun nedenini bilim insanının sürekli çalışmalar, araştırmalar yapan ve icat ile uğraşan bir alg1 içerisinde düşünülmesinden kaynaklandığı söylenebilir. Kız öğrencilerin \%40,36's1, erkek öğrencilerin ise \%39,44'ü bilim insanlarını laboratuvar ortamında göstermişlerdir. Katılımcıların sınıf dağılımı düşünüldüğünde öğrencilerin sınıf düzeyi temel alındığında yapılan değerlendirmede benzer bir sonuç ortaya çıkmaktadır. Çalışmaya katılan öğrencilerin \%79,81'i çizimlerinde bilim insanı laboratuvar ortamında göstermiştir. Oda/ofis ve doğal ortam da diğer ön plana çıkan çalışma alanlarıdır. Çalışmaya katılan öğrencilerin \%9,72'u bilim insanını oda/ofiste, \%7.15 öğrenci ise doğal ortamda (doğa, bahçe) çizmişlerdir. Öğrencilerin \%3.30'u bilim insanının çalışma ortamı olarak kütüphaneyi çizmiştir. Turgut, Öztürk ve Eş (2017) tarafından yapılan çalışmada öğrencilerin bilim insanı ile ilgili genel olarak laboratuvar ortamı ve önlük temalarını tercih ettikleri görülmüştür. Benzer sonuçlara alanyazında rastlamak mümkündür (Barman ve diğerleri, 1997; Camcı Erdoğan, 2013; Fralick ve diğerleri, 2009; Gonsoulin, 2001; Güler ve Akman, 2006; Kaya ve diğerleri, 2008; Korkmaz ve Kavak, 2010; Küçük ve Bağ, 2012; Öcal, 2007; Özel, 2012; Özel ve Doğan, 2013; Özsoy ve Ahi, 2014; Turgut ve diğerleri, 2017; Türkmen, 2008). Elde edilen bu bulgu, öğrencilerin bilim insanının çalışma ortamı ile ilgili kısıtlı bilgiye sahip olduğunu, bilim insanının çoğunlukla laboratuvarda çalışan kişilere ait bir tanımlama olduğunu düşündükleri söylenebilir.

İlköğretim öğrencileri üzerinde yapılan bir başka çalışmada ise bilim insanı ve bilimsel bilgi görüşleri ortaya çıarmak için Kaya, Afacan, Polat ve Urtekin (2013) de öğrencilere açık uçlu sorular yöneltmişlerdir. Öğrencilerin genel olarak bilim insanlarıyla ilgili buluşlar yapan, bilimle uğraşan, insanlığa faydalı olmaya çalışan ve çalışkanlık özelliklerini benimsedikleri görülmektedir. Bilim insanı ile ilgili kalıp düşüncelerin okul öncesi dönemde geliştiğini belirtmektedirler. Varılan sonuçlar göstermektedir ki bilim insanı kavramı öğrencilerde sadece fen bilimleri dersinde duyduğu veya gördüğü kavram ve imgeleri çağrıştırmaktadır. Diğer dersler ve günlük hayatla bağdaştırılarak yapılan çalışmalara yer verilmesi, öğrencilerin bilim insanı algısını değiştirmesine yardımcı olabilir şeklinde ifade etmişlerdir.

Mühendis Çiz testine göre öğrencilerin çoğunun mühendisi bilim insanı algısına benzer kalıp düşünce olarak resmettiği görülmüştür. Öğrencilerin genel olarak erkek mühendis çizdikleri görülmektedir. Çalı̧mamızdaki verilere göre ortaokul öğrencileri çizdikleri resimde mühendisi $\% 76.39$ 'u erkek olarak çizerken, \%11.70'i kadın olarak çizmiştir. Ayrıca araştırmada elde edilen bulgulardan mühendisi kadın olarak genelde (kız öğrencilerde \%10 iken erkek öğrencilerde \%1) kız öğrencilerin çizdiği tespit edilmiştir. Mühendislerin cinsiyeti hakkında görüş çalışmalarında benzer olarak öğrencilerin genelde mühendisleri erkek olarak çizdikleri görülmektedir (Capobianco, Diefes -Dux, Mena ve Weller, 2011; Gülhan ve Şahin,2018; Fralick, Kearn, Thompson ve lyons, 2009; Karataş, Micklos ve Bodner, 
2011; Knight ve Cunningham, 2004). Bu durumu öğrencilerin mühendisliği bir erkek işi gördüğünü ve bu sebeple erkek mühendis çizimlerine ağırlık verdikleri şeklinde açıklayabiliriz. $\mathrm{Bu}$ sonuç $\mathrm{k} ı \mathrm{z}$ öğrencilerin kendi kariyer algıları açısından düşündürücüdür ve bu soruna çözümler üretilmesi gerekmektedir. Karataş, Micklos ve Bodner (2011) araştırmalarında öğrencilerin mühendis kavramlarının kırılgan olduğunu ve değişebildiğini belirtmişlerdir. Bu nedenle öğrencilerin algılarını geliştirmek adına, yazılı, sözlü, sosyal medyada ve eğitim ortamlarında kadın mühendislerin örnekleri ve yaptıkları ürünler ele alınabilir.

Çalışmamızda mühendis çizimlerinde öğrencilerin branş tercihlerine bakıldığında öğrencilerin akıllarına ilk inşaat ve bilgisayar gibi kavramların geldiği, mühendisin inşaat işiyle uğraştığı ve daha çok açık alanda inşaat malzemeleri kullandığı veya bozulan eşyaları tamir eden kişi gibi düşündükleri sonucu elde edilmiştir. Öğrencilerin çok azı mühendisi denetleyen, tasarım yapan biri olarak düşünmektedir. Bu alg1 mühendisin iş tanımı doğrultusunda bakıldı̆̆ında yanlış ve eksik olarak bilindiği açısından öenemli görülmektedir. Mühendisin branşına ait bilgiler incelendiğinde hem kız öğrencilerin hem de erkek öğrencilerin en fazla inşaat mühendisi (\%31) çizdikleri gözlenmiştir. Daha sonra onu takip eden bilgisayar mühendisi (\%25) gelmektedir. Çizimlerde yine branş olarak elektrik mühendisinin, makine mühendisinin, ziraat mühendisinin de yer aldığ1 görülmektedir. Bu sonuçlar öğrencilerin mühendis hakkında eksik bilgilerinin olduğunu göstermektedir. Gündelik yaşamda mühendislerin iş tanımının yanlış yapılması, okul hayatında ise yeterince bilgi verilmemesi bu duruma sebep olabilir. İlgili alan yazın incelendiğinde, öğrencilerin mühendisleri tamirci olarak düşündüğünü veya bir şeyin kurulmas1 yada, çoğunlukla fiziksel çaba gerektiren işlerle ilgilendiklerini ifade etmiştir (Aswad, Vidican ve Samulewicz, 2011; Gibbons, Hirsch, Kimmel, Rockland ve Bloom, 2004; Gülhan ve Şahin,2018; Oware, 2008; Oware, Capobianco ve Diefes-Dux, 2007; Powell, Dainty ve Bagilhole, 2012).Örnek olarak, Knight ve Cunningham (2004) da yaptıklar1 çalışmalarında öğrencilerin mühendisleri inşa eden, bir şeyleri tamir eden insanlar olarak gördüğü sonucuna ulaşmışlardır. Benzer olarak Cunningham, Lachapelle ve Lindgren (2005) yine öğrencilerin mühendisleri daha çok tamir ve inşa etme işleri ile uğraştığına ulaşmışlardır. Araştırmalarda genelde öğrencilerin mühendisliği daha çok erkek mesleği olarak gördükleri bunun da sebebini daha çok güç gerektiren işler yapmaları gerektiği şeklinde yorumladıkları görülmüştür (Knight ve Cunningham, 2004; Capobianco, Diefes -Dux, Mena ve Weller, 2011). Benzer olarak Koyunlu, Ünlü ve Dökme (2016) de özel yetenekli ortaokul seviyesindeki öğrencilerle yapmış oldukları çalışmalarında öğrencilerin mühendis ile ilgili algıları incelenmiştir. Çizimlere bakıldığında çoğunun inşaat mühendisi çizdiği görülmüştür. Çalışma bulguları ve ilgili alan yazın bir bütün halinde incelendiğinde, 2016 yılında MEB Yenilik ve Eğitim Teknolojileri Genel Müdürlüğü tarafından yayımlanan "STEM Eğitimi Raporu" (MEB, 2016) ve 2018 Fen Bilimleri Dersi Öğretim Programında (MEB, 2018) Fen, Mühendislik ve Girişimcilik Uygulamaları kapsamında dahil olan "STEM" yaklaşımının öğrencilerdeki bilim ve mühendis algılarında belirgin bir değişik meydana getirmediği tespit edilmiştir.

Çalışmada elde edilen sonuçlar bir bütün halinde incelendiğinde araştırma sonuçlarından yola çıkarak program geliştiricilere, öğretmenlere ve araştırmacılara şu önerilerde bulunulabilir; 
- Öğrencilerin bilim insanı ve mühendislik algılarında cinsiyetle ilgili klasik düşüncelere (erkek) sahip oldukları tespit edilmiştir. Bunu değiştirmek ve öğrencilerin STEM algılarını geliştirmek adına, okul öncesinden başlayarak ortaokul sınıflarında bilim insanı ve mühendislikle ilgili adımların atılması yararlı olacaktır. Bilim insanı ve mühendis algısını geliştirmek için STEM eğitiminin uygun olduğuna dair kantlar mevcuttur (Gülhan ve Şahin, 2016). Bilimin, bilim insanının ve mühendisin özellikleri daha ayrıntılı ve günlük yaşam örnekleri ile işlenebilir.

- Öğretmenler öğretim yaptıkları konu alanlarına uygun, öğrencilerin mühendislik süreçlerini algılayabilecekleri, disiplinler arası etkinlikler tasarlayabilir.

- Mühendislik fakülteleri, matematik, bilim insanı vs. ile iş birliği halinde çeşitli kurumlarla ortak çalışıp öğrencilere bir meslek olarak bilim insanı ve mühendisliği tanıtma faaliyetleri düzenlenebilir.

- Okul dışı geziler düzenlenerek mühendislerin, bilim insanlarının çalıştıkları ortamlar ziyaret edilebilir. Bu sayede öğrenciler mühendisleri çalıştıkları ortamda gözleme fırsatı bulabilirler ve bu durum da öğrencilerin STEM alanında bir kariyer tercihinde bulunmalarında etkili olabilir.

- Türkiye'nin diğer tüm bölgelerini içerecek, diğer tüm okul kademelerini kapsayacak, daha geniş katılımlı ve daha zengin veri toplama araçları kullanılarak çalışmalar yapılması, öğrencilerin STEM alanlarına yönelik zihinsel yapılarını ortaya koymada daha genel yorumlar yapmada etkili olabileceği için önerilebilir.

- Benzer çalışmaların farklı örneklem ve desenlerle zenginleştirilmesi önerilebilir. Çalışma, öğretmen adaylarına ve öğretmenlere uygulanarak farklı örneklemler üzerinde çalışılabilir.

\section{Kaynakça}

A ğgül Yalçın, F. (2012). Öğretmen adaylarının bilim insanı imajının bazı değişkenlere göre incelenmesi. İlköğretim Online, 11(3), 611-628.

Akgül, A., Uçar, M. K., Öztürk, M. M. ve Ekşi, Z. (2013). Mühendislik eğitiminin iyileştirilmesine yönelik öneriler, geleceğin mühendisleri ve işgücü analizi. Süleyman Demirel Üniversitesi Fen Bilimleri Enstitüsü Dergisi, 14-18.

Akpınar, B. ve Aydın, K. (2007). Eğitimde değişim ve öğretmenlerin değişim algıları (Change in Education and Teachers' Perceptions of Change). Eğitim ve Bilim Education and Science. Firat Üniversitesi, 32(144).

Aswad, N. G., Vidican, G., \& Samulewicz, D. (2011). Creating a knowledge-based economy in the United Arab Emirates: realising the unfulfilled potential of women in the science, technology and engineering fields. European Journal of Engineering Education, 36(6), 559-570. https:/ / doi.org/10.1080/03043797.2011.624174

Ayar, M. C., \& Saka, Y. (2014). Robotics etkinlikleri: İlgi gelişim aşamaları ve kariyer tercihleri. 11. Ulusal Fen Bilimleri ve Matematik Eğitimi Kongresi. Adana, 1114 Eylül 2014.

Bă̆, H. (2013). 4. ve 5. sınıföğrencilerinin bilim insanı imajları. Yayımlanmamış yüksek lisans tezi, Recep Tayyip Erdoğan Üniversitesi Sosyal Bilimler Enstitüsü, Rize. 
Barman C. R., Ostlund, K. L., Gatto, C. C. \& Halferty, M. (1997). Fifth grade students' perceptions about scientists and how they study and use science. Association for the Education of Teachers in Science (AETS) Conference Papers and Summaries of Presentations, Cincinnati.

Blackley, S., \& Howell, J. (2015). A STEM narrative: 15 years in the making. Australian Journal of Teacher Education, 40(7), 102-112. https:// doi.org/10.14221/ajte.2015v40n7.8

Buldu, M. (2006). Young children's perceptions of scientists: A preliminary study. Educational Research. 121-132. https:// doi.org/10.1080/00131880500498602

Büyüköztürk Ş., Kılıç Çakmak, E., Akgün, Ö. E., Karadeniz, Ş. ve Demirel, F. (2012). Bilimsel araştırma yöntemleri. Ankara: Pegem Akademi.

Camcı Erdoğan, S. (2013). Üstün zekâlı ve yetenekli öğrencilerin bilim insanlarına yönelik algıları. Türk Üstün Zekâ ve Ĕ̆itim Dergisi, 3(1), 13-37.

Capobianco, B. M., Diefes-dux, H. A., Mena, I. \& Weller J. (2011). What is an engineer? implications of elementary school student conceptions for engineering education. Journal of Engineering Education, 100(2), 304-328. https:/ / doi.org/10.1002/j.2168-9830.2011.tb00015.x

Chambers, D.W. (1983). Stereotypic images of the scientist: the draw-a scientisttest. Science Education, 67(2), 255-265. https:/ / doi.org/10.1002/sce.3730670213

Chen, X. (2009). Students Who Study Science, Technology, Engineering, and Mathematics (STEM) in Postsecondary Education. Stats in Brief. NCES 2009161. National Center for Education Statistics.

Cunningham, C., Lachapelle, C. ve Lindgren-Streicher. (2005, June). Assessing elementary school students' conceptions of engineering and technology. Proceedings of the American Society for Engineering Education Annual Conference ve Exposition sunuldu, American Society for Engineering Education.

Çakıcı, E. (2018). Farklı öğretim kademelerindeki öğrencilerde bilim insanı algısının belirlenmesi. Mersin Üniversitesi Ĕ̆itim Fakültesi Dergisi, 10(2), 76-95.

Çakıroğlu, E. (2016, Eylül). MEB yenilik ve eğitim teknolojileri genel müdürlüğ̈̈ tarafindan STEM (Fen, Teknoloji, Mühendislik, Matematik) eğitim raporu. STEM Kongresi'nde sunuldu, Ankara.

Çermik, H. (2013). Öğretmen adaylarının zihinlerinde canlanan resimdeki bilim insanı. Pamukkale Üniversitesi Ĕ̆itim Fakültesi Dergisi, 33(1), 139-153.

Çorlu, M. S. (2014). FeTeMM eğitimi makale çağrı mektubu. TurkishJournal of Education,3(1), 4-10. https:/ / doi.org/10.19128/turje.181071

Çorlu, M. ve Aydın, E. (2016). Evaluation of learning gains through integrated STEM projects. International Journal of Education in Mathematics, Science and Technology, 4(1), 20-29. DOI: 10.18404/ijemst.35021

Dugger, W. E. (2010, December). Evolution of STEM in the United States. In the 6th Biennial International Conference on Technology Education Research'nda sunulmuş bildiri, Gold Coast, Queensland, Australia.

Erkuş, A (2009). Davranış bilimleri için bilimsel araştırma süreci. Ankara: Seçkin Yayıncilik. 
Finson, K. D. (2002). Drawing a scientist: What we do and do not know after fifty years of drawings. School and Science Mathematics, 102(7), 335-345. https:// doi.org/10.1111/j.1949-8594.2002.tb18217.x

Fralick, B., Kearn, J., Thompson, S., \& Lyons, J. (2009). How middle schoolers draw engineers and scientists. Journal of Science Education and Technology, 18(1), 60-73. https:// doi.org/10.1007/s10956-008-9133-3

Gibbons, S. J., Hirsch, L. S., Kimmel, H., Rockland, R., \& Bloom, J. (2004). Middle school students' attitudes to and knowledge about engineering. In International conference on engineering education, Gainesville, FL.

Gonsoulin, W. B. (2001). How do middle school students depict science and scientist? Doctoral Dissertation, Mississippi State, Mississippi.

Güler, T. ve Akman, B. (2006). 6 yaş çocuklarının bilim ve bilim insanı hakkındaki görüşleri. Hacettepe Üniversitesi Eğitim Fakültesi Dergisi, 31, 55-56.

Gülhan, F. ve Şahin, F. (2016). Fen-teknoloji-mühendislik-matematik entegrasyonunun (STEM) 5. sınıf öğrencilerinin kavramsal anlamalarına ve mesleklerle ilgili görüşlerine etkisi. Eğitim Bilimlerinde Nitelikler ve Yenilik Arayışı (Edt: Demirel, Ö. ve Dinçer, S.). Ankara: Pegem Yayıncılık, 283-302. http://dx.doi.org/10.14527/9786053183563b2.019.

Gülhan, F. ve Şahin, F. (2018). Ortaokul 5. ve 7. sınıf öğrencilerinin bilim insanlarına yönelik algılarının karşılaştırmalı olarak incelenmesi. Necatibey Eğitim Fakültesi Elektronik Fen ve Matematik Eğitimi Dergisi, 12(1), 309-338. DOI: 10.17522/balikesirnef.437785

Johnson, A. P. (2014). Eylem araştırması el kitabı (çev. Y. Uzuner ve M. Özten Anay,). Ankara: Anı.

Kara, B. (2013). Ortaokul öğrencilerinin bilim insanına yönelik tutum ve imajlarının belirlenmesi. Yayımlanmış yüksek lisans tezi, Erciyes Üniversitesi Eğitim Bilimleri Enstitüsü, Kayseri.

Kara, B. ve Akarsu, B. (2013). Ortaokul öğrencilerinin bilim insanına yönelik tutum ve imajının belirlenmesi. Journal of European Education 3(1), 8-15.

Karataş, F.O., Micklos, A. \& Bodner, G. M. (2011). Sixth-grade students' views of the nature of engineering and images of engineers. Journal of Sciense Education and Technology,20(2), 123-135. https:/ / doi.org/10.1007/s10956-010-9239-2

Kaya, O. N., Doğan, A. ve Öcal, E. (2008). Turkish elementary school students' images of scientists. Eurasian Journal of Educational Research, 32, 83-100.

Kaya, V.H., Afacan, Ö., Polat, D. ve Urtekin, A. (2013). İlköğretim öğrencilerinin bilim insanı ve bilimsel bilgi hakkındaki görüşleri (Kırşehir ili örneği). Ahi Evran Üniversitesi Kırşehir Eğitim Fakültesi Dergisi (KEFAD), 14(1), 305-325.

Kemaneci, G. (2012). Üstün yetenekli öğrencilerin bilim insanı hakkındaki imajlarının araştırılması. Yayımlanmamış yüksek lisans tezi, Gazi Üniversitesi Eğitim Bilimleri Enstitüsü, Ankara.

Keser, F.F. (2012). Üstün yetenekli öğrencilerin bilim ve bilim insanına yönelik görüşlerinin ve bu görüşleri etkileyen faktörlerin belirlenmesi. Yayımlanmamış yüksek lisans tezi, Gazi Üniversitesi Eğitim Bilimleri Enstitüsü, Ankara.

Kibar-Kavak, G. (2008). Öğrencilerin bilime ve bilim insanına yönelik tutumlarını ve imajların etkileyen faktörler. Yayımlanmamış yüksek lisans tezi, Selçuk Üniversitesi Sosyal Bilimler Enstitüsü, Konya. 
Knight, M. ve Cunningham, C. (2004, Haziran). Draw an Engineer Test (DAET): Development of a tool to investigate students' ideas about engineers and engineering. Paper presented at the annual meeting of the American Society for Engineering Education 'de sunuldu, Salt Lake City, Utah.

Korkmaz, H. ve Kavak, G. (2010). İlköğretim öğrencilerinin bilime ve bilim insanına yönelik imajları. İlköğretim Online, 9(3), 1055-1079.

Koyunlu Ünlü, Z. ve Dökme, İ. (2016). Özel yetenekli öğrencilerin FeTeMM'in mühendisliği hakkındaki imajları. Trakya Üniversitesi Eğitim Fakültesi Dergisi, 7(1), 196-204.

Küçük, M. ve Bă̆g, H. (2012). 4 ve 5. sınıf öğrencilerinin bilim insanı imajlarının karşılaştırılması. Bayburt Üniversitesi Ĕ̆itim Fakültesi Dergisi 7(2), 125-138.

Lantz, H. B. (2009). Science, technology, engineering, and mathematics (STEM) education what form? What function. Baltimore: Report, CurrTech Integrations.

León, J., Núñez, J. L. ve Liew, J. (2015). Self-determination and STEM education: Effects of autonomy, motivation, and self-regulated learning on high school math achievement. Learning and Individual Differences, 43, 156-163. https:/ / doi.org/10.1016/j.lindif.2015.08.017

Lou, S. J., Shih, E. C., Diez, C.R. ve Tseng, K. H. (2011). The impact of problem based learning strategies on STEM knowledge integration and attitudes: an exploratory study among female taiwanese senior high scholl students. International Journal of Technology and Desing Education,21(2),195-215. https:/ / doi.org/10.1007/s10798-010-9114-8

McDuffie, T. E. (2001). "Scientists -Geeks and Nerds?". Science and Children, 38(8), 1619.

Medina-Jerev, W., Middleton, K. V. \& Orihuela-Rabaza, W. (2011). Using the DAST-C to explore Colombian and Bolivian students' images of scientists. International Journal of Science and Mathematics Education, 9, 657-690. https:/ / doi.org/10.1007/s10763-010-9218-3

Merriam, S. B., \& Tisdell, E. J. (2015). Qualitative research: A guide to design and implementation. John Wiley \& Sons.

Miles, M.B. ve Huberman, A.M. (1994). Qualitative data analysis. Thousand Oaks, CA: Sage.

Milli Eğitim Bakanlığı. (2016). STEM eğitimi raporu. Ankara: Milli Eğitim Bakanlığ1 Yenilik ve Eğitim Teknolojileri Genel Müdürlüğü (YEĞITTEK).

Milli Eğitim Bakanlığı. (2018). Fen bilimleri dersi öğretim programı. Ankara: Milli Eğitim Bakanlığ1.

National Academy of Engineering and National Research Council. (2014). STEM integration in K-12 education: Status, prospects, and an agenda for research. Washington, DC: The National Academies Press. doi:10.17226/18612

National Research Council [NRC]. (2012). A Framework for $k-12$ science education: Pratices, crosscutting concepts, and core ideas. Washington DC: The National Academic Press.

Newton, L. D. ve Newton, D. P. (1998). Primary children's conceptions of science and the scientist: is the impact of a National Curriculum breaking down the 
stereotype? International Journal of Science Education, 20(9), 1137-1149. https://doi.org/10.1080/0950069980200909

NRC. (2011). A framework for K-12 science education: Practices, crosscutting concepts, and core ideas. Washington, DC: National Academies.

Nuhoğlu, H., \& Afacan, Ö. (2011). İlköğretim Öğrencilerinin Bilim İnsanına Yönelik Düşüncelerinin Değerlendirilmesi. Ahi Evran Üniversitesi Kırşehir Eğitim Fakültesi Dergisi, 12(3), 279-298.

OECD (2018). Strengthening education for innovation. Retrived from. https://www.oecd.org/sti/outlook/eoutlook/stipolicyprofiles/humanresou rces/strengtheningeducationforinnovation.htm

Oware, E. A. (2008). Examining elementary students' perceptions of engineers, Doctoral dissertation, Purdue University.

Oware, E. A., Capobianco, B. M., \&Diefes-Dux, H. A. (2007). Young children's perceptions of engineers before and after a summer engineering outreach course. Paper presented at the 37th ASEE/IEEE Frontiers in Education Conference, Milwaukee, WI. https://doi.org/10.1109/FIE.2007.4417814

Öcal, E. (2007). İlköğretim 6, 7, 8. sinıf ögrrencilerinin bilim insanı hakkındaki imaj ve görüşlerinin belirlenmesi. Yüksek Lisans Tezi, Gazi Üniversitesi Eğitim Bilimleri Enstitüsü, Ankara.

Özdemir, S. (2016, Eylül). STEM eğitimi için görüşler. STEM Kongresinde sunuldu, Ankara.

Özel, M. (2012). Children's images of scientists: Does grade level make a difference? Educational Sciences: Theory E Practice, 12(4), 3187-3198.

Özel, M. ve Doğan, A. (2013). Gifted students' perceptions of scientists. New Educational Review, 31(1), 217-228.

Özsoy, S. ve Ahi, B. (2014). Çocukların gözüyle “bilim insanı”. Necatibey Eğitim Fakültesi Elektronik Fen ve Matematik Ĕ̈itimi Dergisi, 8(1), 204-230.

Patton, M. Q. (2002). Qualitative research and evaluation methods. Thousand Oaks, CA: Sage.

Powell, A.,Dainty, A., \& Bagilhole, B. (2012). Gender stereotypes among women engineering and technology students in the UK: lessons from career choice narratives. European Journal of Engineering Education, 37(6), 541-556. https:// doi.org/10.1080/03043797.2012.724052

Roberts, A. (2012). A justification for STEM education. Technology And Engineering Teacher, 71(8),1-4.

Ruiz-Mallén, I. ve Escalas, M.T. (2012). Scientists seen by children: a case study in Catalonia, Spain. Science Commutation, 34(4), 520-545. https:/ / doi.org/10.1177/1075547011429199

Sahin, A., Ayar, M. C. ve Adıgüzel, T. (2014). Fen, teknoloji, mühendislik ve matematik içerikli okul sonrası etkinlikler ve öğrenciler üzerindeki etkileri. Kuram ve Uygulamada Ĕ̆itim Bilimleri. $\quad 14(1), \quad 1-26$. https:/ / doi.org/10.12738/estp.2014.1.1876

Sanders, M. (2009). STEM, STEM education, STEMmania. The Technology Teacher,68(4),20-26. 
Schibeci, R.A. ve Sorenson, I. (1983). Elementary school children's perception of scientists. School Science and Mathematics, 83(1), 14-19. https:// doi.org/10.1111/j.1949-8594.1983.tb10087.x

Silverman, D., (2000). Interpreting qualitative data: Methods for analysing talk, text and interaction. Thousand Oaks, CA: SAGE.

Song, J. ve Kim, K. S. (1999) How Korean students see scientists: the images of the scientist. International Journal of Science Education, 21(9), 957-977. https:// doi.org/10.1080/095006999290255

Stake, E.R., (1995). The art of case study research. Thousand Oak, CA: Sage.

Toğrol Y., A. (2013). Turkish students images of scientists. Journal of Baltic Science Education, 12(3), 289-298.

Toğrol, Y., A. (2000). Öğrencilerin Bilim İnsanı İle İlgili İmgeleri. Eğitim ve Bilim, 25(118), 49-57.

Tsai, H. W. (2007). A study of STEM instructional model applied to science and technology injunior high school. Yayımlanmamış yüksek lisans tezi. National Pingtung University of Science and Technology, Pingtung, Taiwan.

Turgut, H., Öztürk, N. ve Eş, H. (2017). Üstün zekâlı öğrencilerin bilim ve bilim insanı alg1s1. Abant İzzet Baysal Üniversitesi Eğitim Fakültesi Dergisi, 17(1), 423-440.

Türkmen, H. (2008). Turkish primary students' perceptions about scientist and what factors affecting the 1mage of the scientists. Eurasia Journal of Mathematics, Science and Technology Education,4(1), 55-61.

Unlu, Z. K., Dokme, I., \& Veli, U. (2016). Adaptation of the science, technology, engineering, and mathematics career interest survey (STEM-CIS) into Turkish. Eurasian Journal of Educational Research, 16(63).

Yar, M. (2017). Secondary school student's views on scientist, inventor and engineer. Unpublished Master Thesis, Abant İzzet Baysal University, Institute of Educational Sciences, Bolu.

Yıldırım, A. ve Şimşek, H., (2008). Sosyal bilimlerde nitel araştırma yöntemleri. Ankara: Seçkin.

Yıldırım, B. ve Altun, Y. (2015). STEM eğitim ve mühendislik uygulamalarının fen bilgisi laboratuvar dersindeki etkinliklerinin incelenmesi. El-Cezerî Fen ve Mühendislik Dergisi ,2(2), 28-40.

Yılmaz, A., Gülgün, C., \& Çağlar, A. (2017). Teaching with STEM applications for 7th class students unit of" force and energy": Let's make a parachute, water jet, catapult, intelligent curtain and hydraulic work machine (bucket machine) activities. Journal of Current Researches on Educational Studies, 7(1), 97-116.

Yin, R. K. (2003). Case Study Research Design and Methods. London: Sage Publications.

\section{Summary}

\section{Introduction}

Basing science education on research has required the establishment of more networks to increase the motivation and collaboration of stakeholders (teachers, students, experts, parents, etc.) STEM education, a new system, has been developed and implemented in order to meet the needs (Dugger, 2010; Lantz, 2009). STEM education 
aims to approach the problems faced by students with a multidisciplinary approach and gain knowledge and skills with a holistic education structure (Şahin, Ayar and Adigüzel, 2014). STEM education is seen as a multidisciplinary approach that continues from the beginning of the school to higher education and covers the whole education process (Çorlu and Aydın, 2016; León, Núñez and Liew, 2015; NRC, 2011; OECD, 2018). In the STEM education process, the aim is not only to gain knowledge and skills, but also to raise awareness about the profession. Students' perceptions and images in their minds are also important in their tendency to have a career as a scientist and engineering profession (Knight and Cunningham, 2004). Similar studies have previously been conducted to determine the perceptions of scientists of the students at different educational stages, determining the gifted students' perception of science and scientists, and examining the effects of STEM education approach on the prospective classroom teachers' perceptions about engineering and technology (Capobianco, Diefes-Dux, Mena and Weller, 2011; Fralick, Kearn, Thompson and Lyons, 2009; Yar, 2017). However, when the relevant literature is examined, it has not been found that there is a study in which both scientist and engineer perceptions of secondary school students are discussed together. In this context, it is thought that this study will contribute to the literature.

\section{Method}

Qualitative methodology was used in this study, in which the secondary school students' perceptions of scientists and engineers were examined (Merriam \& Tisdell, 2015). In this context, Qualitative case study methodology was used. The population of study consists of 12 fifth, sixth and seventh grades students studying in the state secondary schools, in the center of a province located in the Central Black Sea in Turkey in the fall semester of the 2019-2020 academic year. Appropriate sampling method was used to determine the study group of the study (Yildırım and Şimşek, 2008). According to the study, the sampling unit in this study is secondary schools which are in the close environment and easily accessible. The observation unit is all fifth, sixth and seventh grade students studying in these schools. In the study, 545 students participated in the "draw a scientist" test while 521 students took the "draw an engineer" test. In the analysis process of the documents collected in the "Draw Scientist" and "Draw Engineer" tests, content analysis was conducted by taking the opinions of field experts. In the content analysis, the answers and drawings given by the students were evaluated by creating codes and themes (Miles, Huberman, 1994; Silverman, 2000). Later, repeating codes were categorized and themed (Stake, 1995).

\section{Results}

In the study, it was observed that while middle school students firstly drew the scientist gender, most of the male and female students $(74.49 \%)$ drew male scientists. It was observed that the majority $(79.81 \%)$ preferred the laboratory as the working environment of the scientist. Another noteworthy element in the drawings is that there are items such as books, test tubes, microscopes and telescopes in the working environment. According to the "Draw an Engineer" test, it was seen that most of the students portray the engineer as a similar stereotype. It is seen that students generally draw male engineers. According to the data in our study, $76.39 \%$ of middle school 
students drew the engineers as male in the picture they drew while $11.70 \%$ of them portrayed as female. In addition, as the findings obtained in the study, it was determined that female students generally drew engineers as female students $(10 \%$ for female students; $1 \%$ for male students). In our study, considering the branch preferences of the students, it was concluded that the concepts 'construction and computer' firstly came to mind of the students, and they think them like the person who is engaged in construction work, mostly uses construction materials in open area or repairs the damaged items. Few of the students consider the engineer as supervising and designing. When the information on the branch of engineers was examined, it was observed that both female students and male students mostly drew the construction engineer (31\%); then the computer engineer comes (25\%). It is seen that the drawings also includes electrical engineer, mechanical engineer, agricultural engineer as branches.

\section{Discussion}

When the relative literature was examined in line with the study, it was observed that the students portray the scientist as male regarding gender, while they mostly depict laboratory regarding the working environment, and they mostly preferred $(70.6 \%)$ laboratory materials in their drawings. Unlike these studies, there are also analyzes that conclude that the scientist can be both male and female. Bağ (2013), in his study that he conducted with fourth and fifth grade students, found that the scientist can be both male and female in the students' drawings. In the opinion studies on the gender of engineers, it is similarly seen that students generally draw engineers as male (Capobianco, Diefes -Dux, Mena and Weller, 2011; Fralick, Kearn, Thompson and lyons, 2009; Karataş, Micklos and Bodner, 2011; Knight and Cunningham, 2004). Ünlü and Dökme (2016), in another study they conducted in our country, found that students consider engineering as a male job and therefore focused on male engineer drawings (Aswad, Vidican and Samulewicz, 2011; Gibbons, Hirsch, Kimmel, Rockland and Bloom, 2004; Oware, 2008; Oware, Capobianco and Diefes-Dux, 2007; Powell, Dainty and Bagilhole, 2012). Similarly, when the relative literature is examined, the students stated that they consider engineers as repairmen or that engineers they are interested in setting up something or mostly in jobs that require physical effort (Aswad, Vidican and Samulewicz, 2011; Gibbons, Hirsch, Kimmel, Rockland and Bloom, 2004; Oware, 2008; Oware, Capobianco and Diefes-Dux, 2007; Powell, Dainty and Bagilhole, 2012). For example, Knight and Cunningham (2004) concluded in their study that students consider engineers as people who build and repair things. When the findings of the study and the relative literature are examined as a whole, it is observed that the "STEM Education Report" published by the Ministry of Education General Directorate of Innovation and Educational Technologies in 2016 and the "STEM" approach included in the 2018 Science Curriculum within the scope of Science, Engineering and Entrepreneurship Applications do not make a significant change in the perceptions of engineers. 


\section{Pedagogical Implications}

Similar studies have been conducted in the relevant literature, such as determining the perception of scientists of students at different educational stages, determining the gifted students' perception of science and scientists and examining the effects of STEM education approach on the prospective classroom teachers' perceptions about engineering and technology (Capobianco, Diefes-Dux, Mena, \& Weller, 2011. ; Fralick, Kearn, Thompson, \& Lyons, 2009; Yar, 2017) However, when the relevant literature is examined, it has not been found that there is a study in which both scientist and engineer perceptions of secondary school students are discussed together. It is believed that an effective STEM education will allow students to choose a career in science and engineering and acquire 21st century skills such as entrepreneurship, innovation, and creative and critical thinking. it is thought that this study examining students' perceptions of engineering and scientists will contribute to the studies to be carried out on STEM education.

\section{Araştırmanın Etik Taahhüt Metni}

Yapılan bu çalışmada bilimsel, etik ve alıntı kurallarına uyulduğu; toplanan veriler üzerinde herhangi bir tahrifatın yapılmadığı, karşılaşılacak tüm etik ihlallerde "Cumhuriyet Uluslararası Eğitim Dergisi ve Editörünün" hiçbir sorumluluğunun olmadığı, tüm sorumluluğun Sorumlu Yazara ait olduğu ve bu çalışmanın herhangi başka bir akademik yayın ortamına değerlendirme için gönderilmemiş olduğu sorumlu yazar tarafından taahhüt edilmiştir.

\section{Authors' Biodata/ Yazar Bilgileri}

Ebru ÖZTÜRK İRTEM, Tokat Gaziosmanpaşa Üniversitesi, Eğitim Bilimleri Enstitüsü, Matematik ve Fen Bilimleri Eğitimi Ana Bilim Dalında Ocak 2021 itibari ile Yüksek Lisans Tez çalışmasını tamamlamıştır.

Ebru Öztürk İrem completed her Master's thesis as of January 2021 in the Department of Mathematics and Science Education, Institute of Educational Sciences, Gaziosmanpaşa University, Tokat.

Hanife Gamze HASTÜRK, Tokat Gaziosmanpaşa Üniversitesi, Eğitim Fakültesi, Temel Eğitim Bölümünde Doktor Öğretim Üyesi olarak çalışmaktadır.

Hanife Gamze Hastürk is working an Assistant Professor at Tokat Gaziosmanpaşa University, Faculty of Education, Department of Primary Education. 